\title{
Long-term spatiotemporal stability and dynamic changes in the haemoparasite community of spiny mice (Acomys dimidiatus) in four montane wadis in the St. Katherine Protectorate, Sinai, Egypt
}

Mohammed Alsarraf', Małgorzata Bednarska', Eman M. E. Mohallal², Ewa J. Mierzejewska', Jolanta Behnke-Borowczyk ${ }^{3}$, Samy Zalat ${ }^{4}$, Francis Gilbert ${ }^{5}$, Renata Welc-Falęciak', Agnieszka Kloch ${ }^{6}$, Jerzy M. Behnke $e^{5}$ and Anna Bajer ${ }^{1 *}$

\begin{abstract}
Background: Long-term field studies of parasite communities are rare but provide a powerful insight into the ecological processes shaping host-parasite interactions. The aim of our study was to monitor long-term trends in the haemoparasite communities of spiny mice (Acomys dimidiatus) and to identify the principal factors responsible for changes over a 12 year period.
\end{abstract}

Methods: To this end we sampled four semi-isolated populations of mice $(n=835)$ in 2000, 2004, 2008 and 2012 in four dry montane valleys (wadis) located in the Sinai Massif, Egypt.

Results: Overall $76.2 \%$ of spiny mice carried at least one of the five haemoparasite genera (Babesia, Bartonella, Haemobartonella, Hepatozoon, Trypanosoma) recorded in the study. Prevalence of haemoparasites varied significantly between the sites with the highest overall prevalence in Wadi Tlah and the lowest in W. El Arbaein, and this changed significantly with time. In the first two surveys there was little change in prevalence, but by 2008 , when the first signs of a deepening drought in the region had become apparent, prevalence began to drift downwards, and by 2012 prevalence had fallen to the lowest values recorded from all four sites over the entire 12-year period. The overall mean species richness was $1.2 \pm 0.03$, which peaked in 2004 and then dropped by more than $50 \%$ by 2012 . Species richness was highest among mice from Wadi Tlah and peaked in age class 2 mice (young adults). Site was the most significant factor affecting the prevalence of individual parasite species, with Trypanosoma acomys and Hepatozoon sp. occurring mainly in two wadis (W. Tlah \& W. Gharaba). In four of the five genera recorded in the study we observed a significant drop in prevalence or/and abundance since 2004, the exception being Hepatozoon sp.

Conclusions: During the 12-year-long period of study in the Sinai, we observed dynamic changes and possibly even cycles of prevalence and abundance of infections which differed depending on parasite species. Although the exact reasons cannot be identified at this time, we hypothesize that the effects of a 15-year-long scarcity of rainfall in the local environment and a fall in host densities over the period of study may have been responsible for a drop in transmission rates, possibly by a negative impact on vector survival.

Keywords: Acomys dimidiatus, Acomys russatus, haemoparasites, Haemobartonella, Bartonella, Hepatozoon, Trypanosoma, Babesia, Species-richness, Prevalence, Abundance, Sinai, Drought, Between year variation

\footnotetext{
* Correspondence: anabena@biol.uw.edu.pl

${ }^{1}$ Department of Parasitology, Institute of Zoology, Faculty of Biology,

University of Warsaw, 1 Miecznikowa Street, 02-096, Warsaw, Poland

Full list of author information is available at the end of the article
} 


\section{Background}

Long-term field studies of parasite communities provide a powerful insight into ecological and evolutionary processes shaping host-parasite interactions over time. Small mammals, especially rodents, are good model hosts for such studies because their populations are abundant, heterogenous and highly dependent on environmental factors, including food availability and climatic conditions [1-3]. The high heterogeneity and the dynamic betweenand within-year variation of rodent populations allow also investigation of the relative contribution of a range of quantifiable intrinsic and extrinsic factors underlying some of the dominant patterns of variation in parasitic infections observed in the field [4-7]. Each rodent community can be regarded as comprising a set of different functional subgroups including, for example, settled, territorial adults of both sexes and mobile juveniles, which may differ in their exposure and susceptibility to infection [8].

Climatic conditions are believed to play a crucial role in shaping plant or animal communities in different habitats, including those living in arid environments such as the deserts of the Middle East, and are likely also to have a major impact on the parasite communities of the indigenous hosts. However, other than in short-term catastrophic events (e.g. earthquakes, intense storms etc.), the influence of climatic changes is likely to be slow over a prolonged period of time and hence long-term ecological studies are essential to identify links between changing climatic conditions and disease.

In earlier studies we have shown that the haemoparasite communities of Acomys dimidiatus vary markedly between subpopulations of spiny mice living in four distinct dry semi-isolated desert valleys (wadis) in the Sinai mountains of Egypt. These four wadies are segregated from each other by natural barriers $[9,10]$ and they differ in altitude but ecologically they show many similarities although distinct differences have also been recorded [11]. Such isolated or semi-isolated subpopulations of animals may differ in the stresses to which they are subjected in each site, including pathogens, and hence may experience different selection pressures created by the specific conditions in their home range (the geographical mosaic theory of co-evolution; [12]). Haemoparasites in particular are likely to be an important source of selective pressure on hosts because they are often associated with pathogenicity (e.g. acute babesiosis, trypanosomiasis; [13-15]) and hence, resistance/tolerance of such infections confers enormous fitness benefits [16-18]. In this context it is pertinent that in our first survey in 2000, the haemoparasite community of the spiny mice living in these wadies were more diverse [10] than in our concurrent and subsequent studies on the haemoparasites of common or bank voles in Poland [4, 19-21] or in other studies on rodents [22-24].
We continued to monitor the haemoparasites of the same spiny mouse populations in 2004, 2008 and 2012 in order to assess the stability of the epidemiological patterns that were observed in 2000. Here, building on the resources collected in these four expeditions to the Sinai and the resultant database on natural infections in wild spiny mice, we report on the spacio-temporal stability of some haemoparasite species carried by $A$. dimidiatus and on the dynamic changes in others in our study sites. Detailed morphometric data on each animal also allowed the effect of host intrinsic factors on haemoparasites to be assessed. We predicted that the effects of host age and sex would be consistent and repeatedly observable in successive surveys, showing little between-year variation in magnitude of the effect due to co-evolution of the hosts and parasites involved. Haemoparasites are vector-borne pathogens (VBP) and in short-lived host species, such as spiny mice, we would expect a significant increase in the prevalence of VBP with host age, as the probability of being infested with ticks or fleas carrying VBP increases also with host age. However, host immune responses to each of the haemoparasites differ, and where hostprotective immunity is generated, we would also expect both prevalence and abundance of infection to decline in the oldest age class [25]. We predicted that extrinsic factors (unique abiotic conditions associated with certain wadi and/or particular years of study) would have a greater influence resulting in repeatable patterns (for between-site differences) or distinct betweensurvey dynamics (for between-year differences). While abiotic conditions are largely 'unpredictable' for both hosts and parasites, the climatic changes in the Sinai have been well documented [26-28] and in this longterm study of the parasites of spiny mice we had an opportunity to observe the impact of decreasing water availability on host and parasite populations/communities. Egypt is the most arid country on Earth [29], classified as 'hyper-arid' in climatology. Because of the alarming reduction in the water supply in the montane wadies of S. Sinai as a consequence of a long period (15 years) of no or only very low rainfall and the resulting increasing aridity of the local environment with associated loss of arable land (Bedouin gardens), clearly apparent during the expeditions in 2008 and 2012 (compared with the first two expeditions in 2000 and 2004), we expected marked differences in parasite community structure over this period of 12 years. For parasite isolates obtained in 2004-2012 we carried out also preliminary molecular characterization and phylogenetic analyses. Our data provide a novel insight into the ecology of the haemoparasites of rodent hosts living in semi-isolated, hyper-arid habitats, about which little is currently known. 


\section{Methods}

\section{Field studies in Sinai, Egypt}

Fieldwork was conducted over 4-5 -week periods in August-September in 2000, 2004, 2008 and 2012 and was based at the Environmental Research Centre of Suez Canal University $(2000,2004)$ or at Fox Camp $(2008,2012)$ in the town of St Katherine, South Sinai, Egypt. Trapping was carried out in four montane wadis (dry valleys) in the vicinity of St Katherine. The local environment and general features of the four study sites (Wadi ElArbaein, W. Gebal, W. Tlah, W. Gharaba), as well as their spatial relationships with one another, have been described elsewhere [9]. At each site, rodents were caught live in Sherman traps, placed selectively among the rocks and boulders around walled gardens and occasionally along the lower slopes of wadis. These were set out at dusk, and inspected in the early morning before exposure to direct sunlight. All traps were brought into the local or main camp, where the animals were removed, identified and processed. Traps were re-set the following evening.

The three most abundant rodent species (A. dimidiatus, $A$. russatus, $D$. dasyurus) were sampled- sexed, weighed, measured and scrutinized for obvious lesions as described by Behnke et al. [9]. Ectoparasites visible during field examination were removed and placed in $70 \%$ ethanol. Blood and faecal samples were taken and animals were then either fur marked individually or ear clipped and released close to the point of capture, or returned to the main camp at St Katherine for autopsy.

Animals were allocated to three age classes, principally on the basis of body weight and nose-to-anus length. For male and non-pregnant female mice separately, these two measurements were reduced by principal components analysis, and principal component 1 (for males Eigen value $=1.87$ and accounted for $93.5 \%$ of variance and for non-pregnant females the Eigen value was 1.83 , accounting for $91.4 \%$ of variance) together with observations recorded for each animal in the field (for males whether scrotal or non-scrotal, for females whether lactating, perforate or pregnant), was used to guide allocation of animals to three age classes. Full details of the methods used and statistical verification of this approach are given in Behnke et al. [9] (all means are cited \pm one standard error). Age class 1 comprised the youngest animals, mostly weanlings and very young non-reproductively active juveniles (mean weight for males $=17.8 \mathrm{~g} \pm 0.40, n=74$; females $=19.5 \mathrm{~g} \pm 0.31, n=116)$, age class 2 comprised juveniles and young adults (mean weight for males = $28.1 \mathrm{~g} \pm 0.29, n=114$, non pregnant females $=27.4 \pm 0.30$, $n=104$; pregnant females $=28.8 \pm 2.49, n=3$ ), and age class 3 comprised the adult and oldest animals in the study (mean weight for males $=41.5 \pm 0.42, n=184$; nonpregnant females $=40.6 \mathrm{~g} \pm 0.44, \quad n=182$; pregnant females $=47.4 \pm 1.09, n=58)$.

\section{Blood collection and DNA extraction}

Thin blood smears were prepared from drops of blood taken from the retro-orbital plexus using heparinized capillary tubes of animals lightly anaesthetized with ether during examination in the field and from the heart of those that were autopsied. Blood smears were air-dried, fixed in absolute methanol and stained for $1 \mathrm{~h}$ in Giemsa stain in buffer at $\mathrm{pH}$ 7.2. Each smear was examined under oil immersion (×1000 magnification). Parasites were counted in 200 fields of vision. Microscopical observation of stained blood smears was used as the only detection method for study in 2000 and for Babesia spp. In subsequent expeditions, in addition to blood smears, molecular techniques were used for species identification of Bartonella, Hepatozoon and Trypanosoma but confined to samples that were positive by microscopical observation in 2004 and 2008, and as the diagnostic method for all samples in 2012. Blood from the tail vein was collected on FTA classic cards (Whatman, UK) for the long-time preservation of DNA. From the culled animals, $200 \mu \mathrm{l}$ of whole blood were also collected into $0.001 \mathrm{M}$ EDTA and frozen at $-20{ }^{\circ} \mathrm{C}$.

Genomic DNA was extracted from whole blood using DNAeasy Blood \& Tissue kit (Qiagen, USA) or AxyPrep MiniPrep Blood kit (AxyGen, USA) and stored at a temperature of $-20{ }^{\circ} \mathrm{C}$. DNA from FTA cards was cleaned with FTA purification Reagent (Whatman, UK) according to the manufacturer's instructions.

\section{Molecular characterization}

The extracted DNA was subjected to specific PCRs as described in detail in Bajer et al. [4]. The primers and cycling conditions used in this study are listed in a table (Additional file 1). Reactions were performed in $1 \times$ PCR buffer, $0.2 \mathrm{U}$ Taq polymerase, $1 \mu \mathrm{M}$ of each primer and $2 \mu \mathrm{l}$ of the extracted DNA sample. Negative controls were conducted in the absence of template DNA. PCR products were subjected to electrophoresis on a $1.5 \%$ agarose gel, stained with Midori Green stain (Nippon Genetics $\mathrm{GmbH}$ ) and sequenced by a private company (Genomed S.A., Poland).

\section{Genotyping and phylogenetic analysis Bartonella sp.}

One Bartonella isolate obtained from $A$. dimidiatus from W. Tlah in 2004 was genotyped by the amplification and sequencing of a 333-bp fragment of the $r p o B$ region [30].

\section{Hepatozoon}

Thirty nine isolates derived from $A$. dimidiatus and $A$. russatus in 2004, 2008 and 2012 from all sites (Table 1) were investigated by the analysis of a $660 \mathrm{bp} 18 \mathrm{~S}$ rRNA gene fragment [31]. First, all obtained sequences were aligned using MEGA v. 6.0. The phylogenetic analyses 
Table 1 Hepatozoon isolates/variants by the host, site and year of study

\begin{tabular}{|c|c|c|c|c|c|c|c|c|c|c|c|c|c|c|}
\hline & & \multicolumn{4}{|l|}{2004} & \multicolumn{4}{|l|}{2008} & \multicolumn{4}{|l|}{2012} & \multirow[t]{2}{*}{ Total } \\
\hline & & Arbaein & Gebal & Gharaba & Tlah & Arbaein & Gebal & Gharaba & Tlah & Arbaein & Gebal & Gharaba & Tlah & \\
\hline A. dimidiatus & Variant A & 0 & 1 & 1 & 0 & 4 & 3 & 3 & 4 & 5 & 0 & 2 & 9 & 32 \\
\hline \multirow[t]{2}{*}{ A. russatus } & Variant A & 0 & 0 & 0 & 0 & 1 & 1 & 2 & 0 & 0 & 0 & 0 & 1 & 5 \\
\hline & Variant B & 0 & 0 & 1 & 0 & 0 & 0 & 0 & 0 & 0 & 0 & 0 & 1 & 2 \\
\hline Total & & 0 & 1 & 2 & 0 & 5 & 4 & 5 & 4 & 5 & 0 & 2 & 11 & 39 \\
\hline
\end{tabular}

including our sequences (660 bp) and sequences of Hepatozoon spp. deposited in the GenBank database were conducted in MEGA v. 6.0 [32]. A representative tree for $18 \mathrm{~S}$ rDNA sequences was obtained using the Maximum Likelihood method and a Tamura 3parameter $(I+G)$ model.

\section{Trypanosoma}

Forty five isolates derived from A. dimidiatus from 2004, 2008 and 2012 from W. Gebal $(n=1), \mathrm{W}$. Gharaba $(n=15)$ and W. Tlah $(n=29)$ were investigated by the analysis of a $520 \mathrm{bp} 18 \mathrm{~S}$ rRNA gene fragment [33]. The phylogenetic analyses including our sequences (520 bp) and other sequences of Trypanosoma spp. deposited in the GenBank database were conducted in MEGA v. 6.0 [32]. A representative tree for $18 \mathrm{~S}$ rDNA sequences was obtained using the Maximum Likelihood method and a Tamura 3-parameter $(\mathrm{I}+\mathrm{G})$.

\section{Statistical analysis}

Prevalence (percentage of animals infected) was estimated based on microscopical observations and values are reported with the $95 \%$ confidence limits, calculated by bespoke software based on the tables of Rohlf and Sokal [34]. The intensity of infection in each animal was quantified as the number of infected red blood cells (iRBC) [for Babesia, Bartonella, Haemobartonella (Mycoplasma)] or parasites (for Trypanosoma, Hepatozoon) in 200 fields of vision at $\times 1000$ magnification and mean abundance is the average of this measure, including all the sampled animals whether infected or not. Species richness was calculated as the number of different haemoparasite species in each animal. When samples were only positive by PCR (in 2012), an intensity of $1 \mathrm{iRBC} / 1$ parasite in 200 fields of vision was implemented into quantitative statistical analysis.

The statistical approach adopted has been documented comprehensively in our earlier publications $[4,6,7]$. For analysis of prevalence we used maximum likelihood techniques based on log - linear analysis of contingency tables in the software package IBM SPSS (version 21.0.0, IBM Corp). Initially, full factorial models were fitted, incorporating as factors SEX (2 levels, males and females), AGE (3 levels), YEAR of study (4 levels, each of the four surveys), and SITE (4 levels, the four study sites). The presence of parasites was implemented as INFECTION and was considered as a binary factor (2 levels, present or absent). These factors were fitted initially to all models that were evaluated. For each level of analysis in turn, beginning with the most complex model, involving all possible main effects and interactions, those combinations that did not contribute significantly to explaining variation in the data were eliminated in a stepwise fashion beginning with the highest level interaction (backward selection procedure). A minimum sufficient model was then obtained, for which the likelihood ratio of $\chi^{2}$ was not significant, indicating that the model was sufficient in explaining the data. The importance of each term (i.e. interactions involving INFECTION) in the final model was assessed by the probability that its exclusion would alter the model significantly and these values relating to interactions that included INFECTION are given in the text. The remaining terms in the final model that did not include INFECTION are not given but can be made available from the authors on request.

For analyses of quantitative data we used general linear models (GLM) with normal errors implemented in $\mathrm{R}$ version 2.2.1 ( $\mathrm{R}$ Core Development Team) and the residuals were checked for approximate Gaussian distribution. When the residuals failed to meet the requirements of Gaussian model we explored models based on $\log _{10}(\mathrm{X}+1)$ transformed data and generalised linear models with negative binomial or Poisson error structures. Full factorial models that converged satisfactorily were simplified using the STEP procedure and tested for significance using deletion of terms beginning with the highest order interaction by comparing models with or without that interaction. Changes in deviance (DEV) are given for models based on Poisson errors (interpreted as $\mathrm{Chi}^{2}$ values), for models based on Gaussian errors we give $\mathrm{F}$ and for those based on negative binomial errors the likelihood ratio (LR). Minimum sufficient models were then fitted (all significant interactions and main effects plus any main effects that featured in interactions) and the process was repeated to obtain values for changes in deviance, test statistics and probabilities. Finally, if the data did not meet the assumptions of parametric tests, we employed non-parametric tests (Kruskal- Wallis test and the Mann - Whitney $U$-test). 


\section{Ethical issue}

Rodents from St Katherine National Protectorate were sampled by agreement with the St Katherine National Protectorate authorities obtained for each set of fieldwork. A maximum of $40 \%$ of the captured rodents from each site were culled by agreement with the St Katherine National Protectorate authorities.

\section{Results}

Molecular identification of parasite species (2004, 2008 and 2012)

\section{Bartonella sp.}

One Bartonella sp. isolate obtained from $A$. dimidiatus from W. Tlah in 2004 was successfully genotyped by the amplification and sequencing of a 333-bp fragment of the $r p o B$ region. Comparison with the GenBank database revealed that the isolate showed the highest sequence homology (99.37 \%; 317/319 bp) with Bartonella acomydis strain KS2-1 obtained from A. russatus (AB529942). This reference strain was identified in the golden spiny mouse imported from Egypt to Japan as an exotic pet [35].

\section{Hepatozoon sp.}

Thirty nine Hepatozoon sp. isolates obtained from 2004, 2008 and 2012 from all sites and two host species, $A$. dimidiatus and $A$. russatus (Table 1 ), were genotyped by sequencing of a $660 \mathrm{bp}$ fragment of the $18 \mathrm{~S}$ rRNA gene. Two genetic variants of Hepatozoon were identified, variant A and B. Variant A was widespread, identified in $32 \mathrm{~A}$. dimidiatus and 5 A. russatus at all sites (Table 1 ). Four representative sequences of this variant were deposited in the GenBank database under the accession numbers KT337467, KT337468, KT337471 and KT337472. Variant B was identified only in 2 A. russatus (1 from W. Gharaba, 2004 and 1 from W. Tlah, 2012). Both sequences of this variant were deposited in the GenBank database under the accession numbers KT337469 and KT337470.

A BLAST search in the GenBank database revealed, that variant A showed the highest sequence homology (96.23 \%) to Hepatozoon sp. AO5 from the olive grass mouse, Abrothrix olivaceus, from Chile (FJ719818) and $96.06 \%$ sequence homology to $H$. ayorgbor from the royal python, Python regius, from Ghana (EF157822). Variant B showed the highest sequence homology (96.75\%) to $H$. ayorgbor from $P$. regius (EF157822) and $97.09 \%$ to Hepatozoon sp. AO5 from A. olivaceus (FJ719818). Both variants showed a lower sequence homology with Hepatozoon isolates from jerboas Jaculus orientalis and J. jaculus (95.5-96.5 \%) [36].

Alignment of our two Hepatozoon variants revealed a difference of 11 nucleotides between them. Alignment of these two variants with the two most similar sequences of Hepatozoon from the GenBank database is given in
Additional file 2. Phylogenetic analysis revealed that our Hepatoozon sequences grouped together with genotypes/ species of Hepatozoon derived from other species of rodents from different parts of the world [i.e. A.olivaceus, A. sanborni, Bandicota indica, Jaculus spp., Sciurus vulgaris, Clethrionomys (Myodes) glareolus] and from some species of reptiles, but were distant from Hepatozoon genotypes/species found in carnivores (i.e. $H$. felis, H. americanum, H. ursi) (Fig. 1).

\section{Trypanosoma sp.}

Forty - five Trypanosoma isolates were obtained and genotyped: 13 isolates from 2004, 10 isolates from 2008 and 22 isolates from 2012. All isolates were derived from A. dimidiatus, mostly from just two wadis where this parasite was found during the study period: 15 isolates from W. Gharaba and 29 isolates from W. Tlah. Additionally, one isolate from W. Gebal was obtained and genotyped. Isolates were genotyped by the amplification and sequencing of a 520-bp fragment of the $18 \mathrm{~S}$ rRNA gene. Two genetic variants of Trypanosoma were identified, variant A and B. Variant A was widespread, and identified in 44 A. dimidiatus from W. Gebal, Gharaba and Tlah (2004, 2008 and 2012). One representative sequence of variant A was deposited in the GenBank database under the accession number KT337473. Variant B was identified only in one isolate from $A$. dimidiatus from W. Tlah in 2012. The sequence of this variant was deposited in the GenBank database under the accession number KT337474.

A BLAST search in the GenBank database revealed, that both variants $\mathrm{A}$ and $\mathrm{B}$ showed the highest sequence homology to a Trypanosoma sp. isolate from A. dimidiatus from one of our own earlier expeditions to Egypt (100\%; HQ324793) (direct submission). The next closet matches (95.94 \%) of variant A were Trypanosoma sp. from Anderson's red-backed vole, Eothenomys andersoni, from Japan (AB242276) and T. microti from the field vole, Microtus agrestis, from the UK (AJ009158). Variant B showed the next highest homology (97.39 \%) to Trypanosoma sp. B08471 from a squirrel flea, Ceratophyllus (Monopsyllus) sciurorum from the Czech Republic (KF054111) and to T. microti from M. agrestis from the UK (AJ009158).

Alignment of our two Trypanosoma variants revealed a difference of 7 nucleotides between them. Alignment of these two variants with the most similar sequences of Trypanosoma from the GenBank database is presented in Additional file 3. Phylogenetic analysis revealed that our Trypanosoma sequences grouped together with species of Trypanosoma derived from other species of rodents from different parts of the world (T. blanchardi, T. evotomys, $T$. grosi, T. kuseli, T. lewisi, T. microti, T. musculi) and were distant from the key pathogenic species, T. brucei or T. cruzi (Fig. 2). 


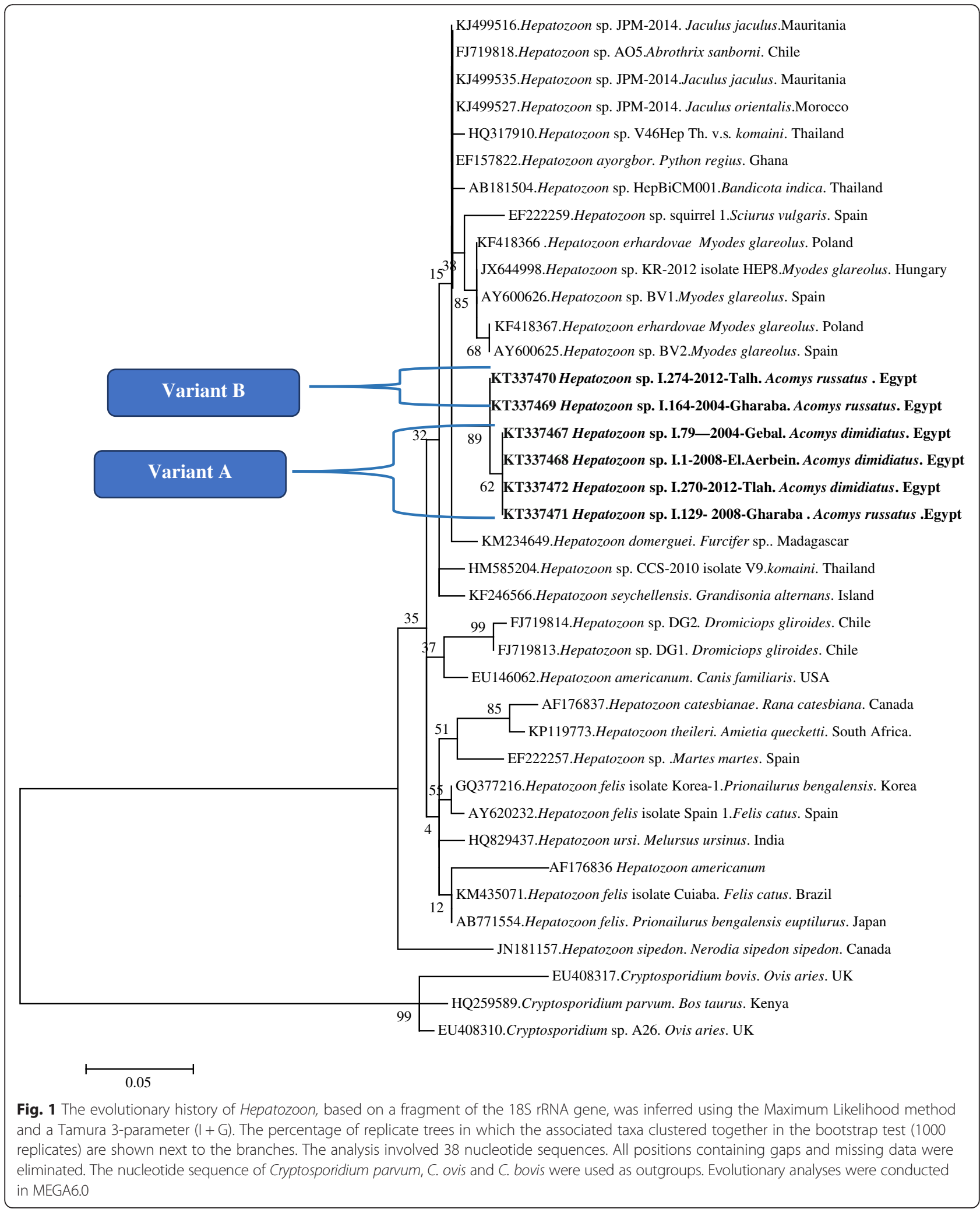




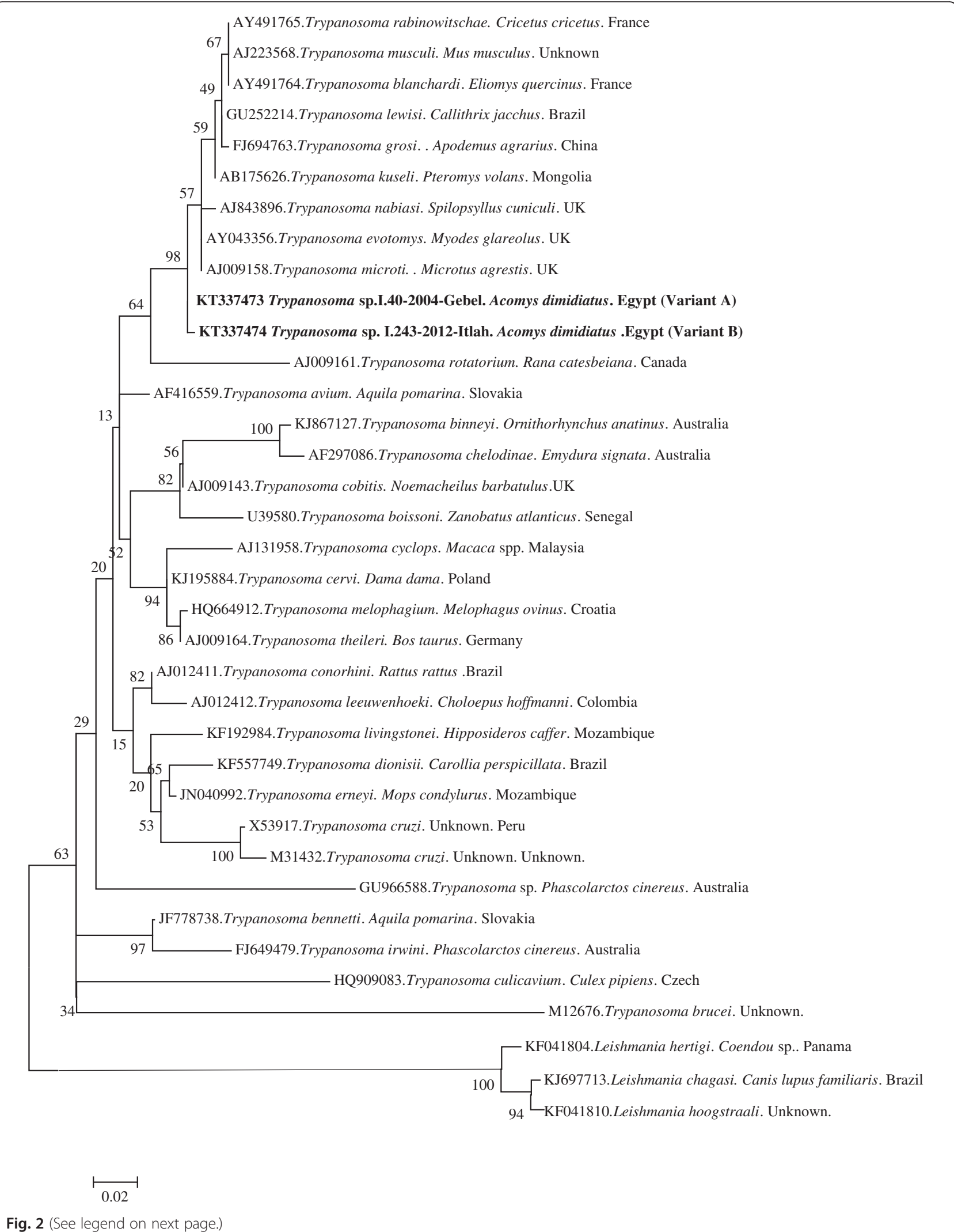

Fig. 2 (See legend on next page.) 
(See figure on previous page.)

Fig. 2 The evolutionary history of Trypanosoma, based on the fragment of the 18S rRNA gene, was inferred using the Maximum Likelihood method and a Tamura 3-parameter $(I+G)$. The percentage of replicate trees in which the associated taxa clustered together in the bootstrap test (1000 replicates) are shown next to the branches. The analysis involved 36 nucleotide sequences. All positions containing gaps and missing data were eliminated. The nucleotide sequence of Leishmania hertigi, L. chagasi and L. hoogstraali were used as outgroups. Evolutionary analyses were conducted in MEGA6.0

\section{Environmental study in Sinai in the period 2000-2012 Acomys dimidiatus}

A total of 857 individual spiny mice were caught over the four surveys (Table 2) and blood samples of sufficient quality to assess microscopically were obtained from 835 (Table 3). Values for the trapping effort and the resulting success in terms of mice caught/100 trap hours (th), and number of mice as a percentage of traps deployed in the field are summarized by wadi and year of survey in Table 2. Analysis of these data by the

Table 2 Trapping effort and relative population size of $A$. dimidiatus

\begin{tabular}{|c|c|c|c|c|c|}
\hline & & $\begin{array}{l}\text { Trap } \\
\text { Hours }\end{array}$ & $\begin{array}{l}\text { No. of } \\
\text { A. dimidiatus }\end{array}$ & $\begin{array}{l}\text { Mice/100 } \\
\text { th }^{\mathrm{a}}\end{array}$ & $\begin{array}{l}\text { Trap } \\
\text { success (\%) }\end{array}$ \\
\hline \multirow[t]{5}{*}{ Arbaein } & 2000 & 2723 & 63 & 2.31 & 32.0 \\
\hline & 2004 & 3265 & 43 & 1.32 & 16.8 \\
\hline & 2008 & 3714 & 69 & 1.86 & 25.3 \\
\hline & 2012 & 3918 & 67 & 1.71 & 23.4 \\
\hline & Combined & 13620 & 242 & 1.78 & 23.9 \\
\hline \multirow[t]{5}{*}{ Gebel } & 2000 & 1838 & 32 & 1.74 & 21.3 \\
\hline & 2004 & 2112 & 43 & 2.04 & 27.4 \\
\hline & 2008 & 3831 & 43 & 1.12 & 16.4 \\
\hline & 2012 & 3675 & 47 & 1.28 & 17.2 \\
\hline & Combined & 11456 & 165 & 1.44 & 19.6 \\
\hline \multirow[t]{5}{*}{ Gharaba } & 2000 & 2136 & 28 & 1.31 & 16.5 \\
\hline & 2004 & 2913 & 61 & 2.09 & 29.2 \\
\hline & 2008 & 4314 & 54 & 1.25 & 16.1 \\
\hline & 2012 & 3989 & 52 & 1.30 & 17.2 \\
\hline & Combined & 13352 & 195 & 1.46 & 19.2 \\
\hline \multirow[t]{5}{*}{ Tlah } & 2000 & 2199 & 46 & 2.09 & 27.7 \\
\hline & 2004 & 2117 & 70 & 3.31 & 45.2 \\
\hline & 2008 & 5344 & 80 & 1.50 & 20.1 \\
\hline & 2012 & 3988 & 59 & 1.48 & 19.9 \\
\hline & Combined & 13648 & 255 & 1.87 & 25.1 \\
\hline \multirow[t]{5}{*}{ Combined } & 2000 & 8896 & 169 & 1.90 & 24.7 \\
\hline & 2004 & 10407 & 217 & 2.09 & 27.9 \\
\hline & 2008 & 17203 & 246 & 1.43 & 19.3 \\
\hline & 2012 & 15570 & 225 & 1.45 & 19.4 \\
\hline & $\begin{array}{l}\text { Grand } \\
\text { total/average }\end{array}$ & 52076 & 857 & 1.65 & 22.0 \\
\hline
\end{tabular}

${ }^{a}$ No of animals caught per 100 trap hours (th)

${ }^{\mathrm{b}}$ Trap success $=$ percentage of traps occupied by a mouse after overnight deployment of traps in the study sites
Kruskal-Wallis test with either YEAR or SITE as the explanatory factor on each of the variables listed in turn, revealed that the only significant effect was that of YEAR on the number of trap hours $\left(\chi_{3}^{2}=11.5, P=0.009\right)$. As can be seen in Table 2, the number of trap hours was larger in 2008 and 2012 compared with the two earlier years.

The structure and the sample sizes of each subset of the host population that was assessed for haemoparasites, is shown in Table 3 by site and year of study, host sex and age. The numbers of mice sampled differed significantly between the wadis $\left(\chi_{3}^{2}=25.4, P<0.001\right)$, with most from W. Tlah and the least from W. Gebal. The distribution of mice among age classes also varied significantly between the sexes (SEX $\left.\times \mathrm{AGE}, \chi_{2}^{2}=6.8, P=0.033\right)$ and between the four surveys (YEAR $\times$ AGE, $\chi_{6}^{2}=15.2, P=0.019$ ), and these effects are taken into consideration in further analyses.

\section{Haemoparasites - all species combined}

Overall $76.2 \%$ (72.61-79.42) of the 835 spiny mice carried at least one of the five haemoparasite genera recorded in the study. Prevalence varied significantly between the sites (Table 4; SITE $\times$ INFECTION, $\chi_{3}^{2}=34.5, P<0.001$ ) with the highest overall prevalence in W. Tlah and the lowest in W. El Arbaein, and it changed significantly with time (Table 4; YEAR $\times$ INFECTION, $\chi_{3}^{2}=99.1, P<0.001$ ), although the pattern of change of prevalence with time varied between the sites (Fig. 3a; YEAR $\times$ SITE $\times$ INFECTION, $\left.\chi_{9}^{2}=29.7, P<0.001\right)$. In the first two surveys there was little change in prevalence, but in 2008 prevalence began to drift downwards, especially in W. Gharaba and by 2012, prevalence had fallen in all four sites relative to 2000 , although the least change was observed in mice from W. Tlah. Age on its own was just the wrong side of significance (AGE $\times$ INFECTION $\chi_{2}^{2}=5.9, P=0.051$ ) and as can be seen in Table 4, prevalence was lowest among the young age class but only $9 \%$ higher in the intermediate age class and slightly lower among the oldest mice, so overall little change with increasing host age. However, the age of hosts featured also in two interactions, one with year of survey (YEAR $\times$ AGE $\times$ INFECTION, $\left.X_{6}^{2}=13.5, P=0.036\right)$ and one with location of sampling (SITE $\times$ AGE $\times$ INFECTION $\chi_{6}^{2}=19.0$, $P=0.004$ ), which we did not explore further. There was no significant difference in prevalence between the two sexes and SEX did not figure in any of the interactions that were detected. 
Table 3 Numbers of Acomys dimidiatus examined by site, year, host age and sex

\begin{tabular}{|c|c|c|c|c|c|c|c|}
\hline \multirow[b]{2}{*}{ Site } & \multirow[b]{2}{*}{ Year } & \multirow[b]{2}{*}{ Sex } & \multicolumn{3}{|c|}{ Age class } & \multicolumn{2}{|c|}{ Totals } \\
\hline & & & Class1 & Class2 & Class3 & Row & $\begin{array}{l}\text { Site and } \\
\text { year }\end{array}$ \\
\hline \multirow{11}{*}{$\begin{array}{l}\text { El } \\
\text { Arbaein }\end{array}$} & 2000 & Males & 6 & 15 & 7 & 28 & \\
\hline & & Females & 11 & 8 & 11 & 30 & 58 \\
\hline & 2004 & Males & 4 & 5 & 12 & 21 & \\
\hline & & Females & 7 & 6 & 9 & 22 & 43 \\
\hline & 2008 & Males & 3 & 10 & 17 & 30 & \\
\hline & & Females & 11 & 9 & 16 & 36 & 66 \\
\hline & 2012 & Males & 8 & 3 & 18 & 29 & \\
\hline & & Females & 9 & 11 & 15 & 35 & 64 \\
\hline & $\begin{array}{l}\text { All } \\
\text { years }\end{array}$ & Total males & 21 & 33 & 54 & 108 & \\
\hline & & Total females & 38 & 34 & 51 & 123 & \\
\hline & & $\begin{array}{l}\text { Total combined } \\
\text { sexes }\end{array}$ & 59 & 66 & 105 & 231 & \\
\hline \multirow[t]{11}{*}{ Gebal } & 2000 & Males & 3 & 7 & 2 & 12 & \\
\hline & & Females & 3 & 5 & 8 & 16 & 28 \\
\hline & 2004 & Males & 4 & 2 & 8 & 14 & \\
\hline & & Females & 8 & 1 & 20 & 29 & 43 \\
\hline & 2008 & Males & 5 & 2 & 12 & 19 & \\
\hline & & Females & 4 & 5 & 15 & 24 & 43 \\
\hline & 2012 & Males & 4 & 7 & 10 & 21 & \\
\hline & & Females & 7 & 1 & 16 & 24 & 45 \\
\hline & $\begin{array}{l}\text { All } \\
\text { years }\end{array}$ & Total males & 16 & 18 & 32 & 66 & \\
\hline & & Total females & 22 & 12 & 59 & 93 & \\
\hline & & $\begin{array}{l}\text { Total combined } \\
\text { sexes }\end{array}$ & 38 & 30 & 91 & 159 & \\
\hline \multirow[t]{11}{*}{ Gharaba } & 2000 & Males & 1 & 5 & 5 & 11 & \\
\hline & & Females & 2 & 6 & 9 & 17 & 28 \\
\hline & 2004 & Males & 5 & 8 & 12 & 25 & \\
\hline & & Females & 6 & 10 & 19 & 35 & 60 \\
\hline & 2008 & Males & 7 & 3 & 14 & 24 & \\
\hline & & Females & 8 & 5 & 15 & 28 & 52 \\
\hline & 2012 & Males & 1 & 4 & 14 & 19 & \\
\hline & & Females & 6 & 8 & 19 & 33 & 52 \\
\hline & $\begin{array}{l}\text { All } \\
\text { years }\end{array}$ & Total males & 14 & 20 & 45 & 79 & \\
\hline & & Total females & 22 & 29 & 62 & 113 & \\
\hline & & $\begin{array}{l}\text { Total combined } \\
\text { sexes }\end{array}$ & 36 & 49 & 107 & 192 & \\
\hline \multirow[t]{3}{*}{ Tlah } & 2000 & Males & 4 & 9 & 11 & 24 & \\
\hline & & Females & 4 & 5 & 13 & 22 & 46 \\
\hline & 2004 & Males & 2 & 15 & 17 & 34 & \\
\hline
\end{tabular}

Table 3 Numbers of Acomys dimidiatus examined by site, year, host age and sex (Continued)

\begin{tabular}{|c|c|c|c|c|c|c|c|}
\hline & & Females & 7 & 8 & 21 & 36 & 70 \\
\hline & \multirow[t]{2}{*}{2008} & Males & 13 & 12 & 14 & 39 & \\
\hline & & Females & 12 & 12 & 16 & 40 & 79 \\
\hline & \multirow[t]{2}{*}{2012} & Males & 4 & 7 & 10 & 21 & \\
\hline & & Females & 11 & 8 & 18 & 37 & 58 \\
\hline & \multirow{3}{*}{$\begin{array}{l}\text { All } \\
\text { years }\end{array}$} & Total males & 23 & 43 & 52 & 118 & \\
\hline & & Total females & 34 & 33 & 68 & 135 & \\
\hline & & $\begin{array}{l}\text { Total combined } \\
\text { sexes }\end{array}$ & 57 & 76 & 120 & 253 & \\
\hline \multirow{12}{*}{$\begin{array}{l}\text { Total by } \\
\text { year }\end{array}$} & \multirow[t]{3}{*}{2000} & Males & 14 & 36 & 25 & 75 & \\
\hline & & Females & 20 & 24 & 41 & 85 & \\
\hline & & Both sexes & 34 & 60 & 66 & 160 & \\
\hline & \multirow[t]{3}{*}{2004} & Males & 15 & 30 & 49 & 94 & \\
\hline & & Females & 28 & 25 & 69 & 122 & \\
\hline & & Both sexes & 43 & 55 & 118 & 216 & \\
\hline & \multirow[t]{3}{*}{2008} & Males & 28 & 27 & 57 & 112 & \\
\hline & & Females & 35 & 31 & 62 & 128 & \\
\hline & & Both sexes & 63 & 58 & 119 & 240 & \\
\hline & \multirow[t]{3}{*}{2012} & Males & 17 & 21 & 52 & 90 & \\
\hline & & Females & 33 & 28 & 68 & 129 & \\
\hline & & Both sexes & 50 & 49 & 120 & 219 & \\
\hline \multirow{3}{*}{$\begin{array}{l}\text { Total by } \\
\text { sex }\end{array}$} & & Males & 74 & 114 & 183 & 371 & \\
\hline & & Females & 116 & 108 & 240 & 464 & \\
\hline & & Both sexes & 190 & 222 & 423 & 835 & \\
\hline
\end{tabular}

The mean species richness was $1.2 \pm 0.03$. The best fit model was one with a Gaussian error structure $(\mathrm{YEAR}+\mathrm{SITE}+\mathrm{AGE}+\mathrm{YEAR} \times \mathrm{SITE}+\mathrm{YEAR} \times \mathrm{AGE}$ on species richness, adjusted $R^{2}=0.31$ ). The data in Table 5 show that species richness peaked in 2004 and dropped by more than $50 \%$ to 2012 (main effect of YEAR, $\left.F_{3,826}=45.9, P<0.0001\right)$, was highest among mice from W. Tlah (main effect of SITE, $F_{3,826}=38.1$, $P<0.0001$ ) and peaked in age class 2 mice (main effect of AGE, $F_{2,826}=5.5, P=0.004$ ). While species richness was consistently highest among mice from $\mathrm{W}$. Tlah, there was significant variation in the rank order of species richness among mice for the other wadis from survey to survey (Fig. 4a; 2-way interaction YEAR $\times$ SITE, $F_{9,820}=7.5$, $P<0.0001)$, as illustrated for example among mice from W. Gharaba for which species richness was second highest in 2000 and 2004, but lowest in 2008 . The profile of species richness across the three age classes also varied between surveys (Fig. 5a; YEAR $\times$ AGE, $\left.F_{6}, 817=3.1, P=0.006\right)$. In three surveys $(2004$, 2008 and 2012), species richness was highest among 
Table 4 Prevalence of haemoparasites by year, site, host sex and age class

\begin{tabular}{|c|c|c|c|c|c|c|}
\hline & Haemoparasites & Babesia spp. & Bartonella spp. & Haemobartonella spp. & Trypanosoma acomys & Hepatozoon spp. \\
\hline \multicolumn{7}{|l|}{ Year } \\
\hline 2000 & $\begin{array}{l}86.3 \\
(79.11-91.34)\end{array}$ & $\begin{array}{l}1.9 \\
(0.44-6.20)\end{array}$ & $\begin{array}{l}2.5 \\
(0.76-7.00)\end{array}$ & $\begin{array}{l}80.0 \\
(72.16-86.30)\end{array}$ & $\begin{array}{l}\mathbf{1 7 . 5} \\
(11.68-25.22)\end{array}$ & $\begin{array}{l}\mathbf{2 0 . 6} \\
(14.26-28.47)\end{array}$ \\
\hline 2004 & $\begin{array}{l}91.2 \\
(88.25-93.47)\end{array}$ & $\begin{array}{l}6.9 \\
(4.91-9.61)\end{array}$ & $\begin{array}{l}8.3 \\
(6.12-11.24)\end{array}$ & $\begin{array}{l}85.2 \\
(81.69-88.17)\end{array}$ & $\begin{array}{l}22.7 \\
(19.08-26.70)\end{array}$ & $\begin{array}{l}29.2 \\
(25.18-33.48)\end{array}$ \\
\hline 2008 & $\begin{array}{l}77.1 \\
(72.86-80.85)\end{array}$ & $\begin{array}{l}3.3 \\
(1.97-5.48)\end{array}$ & $\begin{array}{l}\mathbf{0 . 8} \\
(0.31-2.25)\end{array}$ & $\begin{array}{l}\mathbf{4 5 . 8} \\
(41.09-50.58)\end{array}$ & $\begin{array}{l}\mathbf{1 2 . 1} \\
(9.28-15.53)\end{array}$ & $\begin{array}{l}\mathbf{4 0 . 0} \\
(35.42-44.74)\end{array}$ \\
\hline 2012 & $\begin{array}{l}\mathbf{5 3 . 0} \\
(48.40-57.53)\end{array}$ & $\begin{array}{l}\mathbf{0} \\
(0-0.82)\end{array}$ & $\begin{array}{l}\mathbf{2 . 7} \\
(1.56-4.65)\end{array}$ & $\begin{array}{l}\mathbf{2 7 . 9} \\
(23.92-32.10)\end{array}$ & $\begin{array}{l}\mathbf{1 1 . 9} \\
(9.18-15.16)\end{array}$ & $\begin{array}{l}\mathbf{2 5 . 6} \\
(21.78-29.76)\end{array}$ \\
\hline \multicolumn{7}{|l|}{ Site } \\
\hline Arbaein & $\begin{array}{l}68.8 \\
(64.36-72.98)\end{array}$ & $\begin{array}{l}\mathbf{0 . 9} \\
(0.33-2.27)\end{array}$ & $\begin{array}{l}3.5 \\
(2.08-5.59)\end{array}$ & $\begin{array}{l}66.2 \\
(61.67-70.55)\end{array}$ & $\begin{array}{l}\mathbf{0 . 4} \\
(0.16-1.57)\end{array}$ & $\begin{array}{l}10.4 \\
(7.80-13.61)\end{array}$ \\
\hline Gebal & $\begin{array}{l}72.3 \\
(63.96-79.50)\end{array}$ & $\begin{array}{l}8.2 \\
(4.38-14.45)\end{array}$ & $\begin{array}{l}6.9 \\
(3.61-12.75)\end{array}$ & $\begin{array}{l}71.7 \\
(63.24-78.90)\end{array}$ & $\begin{array}{l}\mathbf{0 . 6} \\
(0.07-4.02)\end{array}$ & $\begin{array}{l}6.3 \\
(3.17-11.88)\end{array}$ \\
\hline Gharaba & $\begin{array}{l}71.9 \\
(62.51-79.80)\end{array}$ & $\begin{array}{l}\mathbf{0 . 5} \\
(0.04-4.43)\end{array}$ & $\begin{array}{l}1.6 \\
(0.25-6.27)\end{array}$ & $\begin{array}{l}\mathbf{4 4 . 8} \\
(35.47-54.56)\end{array}$ & $\begin{array}{l}\mathbf{2 1 . 9} \\
(14.92-30.98)\end{array}$ & $\begin{array}{l}33.9 \\
(25.33-43.58)\end{array}$ \\
\hline Tlah & $\begin{array}{l}\mathbf{8 8 . 5} \\
(85.06-91.34)\end{array}$ & $\begin{array}{l}\mathbf{4 . 0} \\
(2.41-6.30)\end{array}$ & $\begin{array}{l}3.2 \\
(1.81-5.34)\end{array}$ & $\begin{array}{l}\mathbf{5 1 . 4} \\
(46.52-56.24)\end{array}$ & $\begin{array}{l}\mathbf{3 4 . 8} \\
(30.27-39.55)\end{array}$ & $\begin{array}{l}\mathbf{5 8 . 9} \\
(54.04-63.63)\end{array}$ \\
\hline \multicolumn{7}{|l|}{ Sex } \\
\hline Males & $\begin{array}{l}76.0 \\
(70.62-80.73)\end{array}$ & $\begin{array}{l}4.0 \\
(2.21-7.04)\end{array}$ & $\begin{array}{l}3.0 \\
(1.49-5.70)\end{array}$ & $\begin{array}{l}56.9 \\
(51.00-62.58)\end{array}$ & $\begin{array}{l}15.4 \\
(11.55-20.08)\end{array}$ & $\begin{array}{l}28.3 \\
(23.29-33.90)\end{array}$ \\
\hline Females & $\begin{array}{l}76.3 \\
(70.13-81.59)\end{array}$ & $\begin{array}{l}2.4 \\
(0.97-5.43)\end{array}$ & $\begin{array}{l}4.1 \\
(2.04-7.60)\end{array}$ & $\begin{array}{l}58.6 \\
(51.94-65.09)\end{array}$ & $\begin{array}{l}16.2 \\
(11.75-21.64)\end{array}$ & $\begin{array}{l}30.8 \\
(25.03-37.24)\end{array}$ \\
\hline \multicolumn{7}{|l|}{ Age } \\
\hline Class 1 & $\begin{array}{l}69.5 \\
(59.84-77.81)\end{array}$ & $\begin{array}{l}\mathbf{6 . 3} \\
(2.95-12.62)\end{array}$ & $\begin{array}{l}4.2 \\
(1.56-9.94)\end{array}$ & $\begin{array}{l}60.0 \\
(50.30-69.17)\end{array}$ & $\begin{array}{l}15.3 \\
(9.32-23.40)\end{array}$ & $\begin{array}{l}9.5 \\
(5.06-16.61)\end{array}$ \\
\hline Class 2 & $\begin{array}{l}78.8 \\
(74.85-82.40)\end{array}$ & $\begin{array}{l}\mathbf{0 . 9} \\
(0.35-2.28)\end{array}$ & $\begin{array}{l}3.2 \\
(1.86-5.17)\end{array}$ & $\begin{array}{l}57.7 \\
(53.08-62.14)\end{array}$ & $\begin{array}{l}26.6 \\
(22.69-30.84)\end{array}$ & $\begin{array}{l}36.9 \\
(32.56-41.51)\end{array}$ \\
\hline Class 3 & $\begin{array}{l}77.8 \\
(72.12-82.65)\end{array}$ & $\begin{array}{l}\mathbf{2 . 8} \\
(1.33-5.81)\end{array}$ & $\begin{array}{l}3.5 \\
(1.77-6.70)\end{array}$ & $\begin{array}{l}57.0 \\
(50.64-63.11)\end{array}$ & $\begin{array}{l}10.4 \\
(7.03-14.92)\end{array}$ & $\begin{array}{l}35.0 \\
(29.14-41.28)\end{array}$ \\
\hline
\end{tabular}

Significant main effects are highlighted in bold

age class 2 mice, but the pattern was different in 2000 with a peak among the oldest animals.

\section{Babesia spp.}

The overall prevalence of Babesia spp. was just $3.1 \%$ (1.97-4.81). Prevalence varied from $6.9 \%$ in 2004, to zero in 2012, and the difference between the surveys was significant (Table 4; YEAR $\times$ INFECTION, $\chi_{3}^{2}=22.7, P<0.001$ ), as was that also between sites (Table 4; SITE $\times$ INFECTION $\left.\chi_{3}^{2}=21.9, \mathrm{P}<0.001\right)$. Prevalence was highest in $\mathrm{W}$. Gebal and lowest in W. Gharaba, where just one of the 192 spiny mice examined was found to be infected. However, there was also a significant interaction (YEAR $\times$ SITE $\times$ INFECTION, $\chi_{9}^{2}=22.7, P=0.007$ ) and this is illustrated in Fig. 3b. Infections were sporadic in three of the wadis, recorded in only 1 or 2 of the 4 surveys, except in W. Tlah where Babesia was detected in three of the four surveys. There was also a marked peak in prevalence in 2004 in mice from W. Gebal, where otherwise in 2000 and 2012 no infections were detected. Prevalence was higher among the youngest age class (Table 4; AGE $\times$ INFECTION $\chi_{2}^{2}=10.8$, $P=0.004$ ) compared with the older age classes, but there was no significant difference in prevalence between the sexes.

With just 26 out of 835 animals infected with Babesia sp., the overall mean abundance was $0.79 \pm 0.600$ IN/200FV. Quantitative analysis was problematic with parametric models with Gaussian errors on raw and log transformed data failing to generate acceptable distributions of residuals and to those with negative binomial errors failing to converge (See Methods). Therefore, only the main effects were tested using non-parametric tests, with much the same outputs as those for prevalence (Kruskal-Wallis test for the effects of YEAR, $\chi_{3}^{2}=18.6$, $P<0.001$; SITE, $\chi_{3}^{2}=22.5, P<0.001$ and AGE, $X_{2}^{2} 10.1$, $P=0.006)$. There was no significant difference between the sexes (Mann-Whitney $U$ test $Z=-1.37, P=0.17$ ). The mean values are given in Table 5 and the SITE $x$ YEAR effect in Fig. 4b. Mostly mean abundance was less than 0.4 IC/200FV, with the exception of W. Gebal when in 


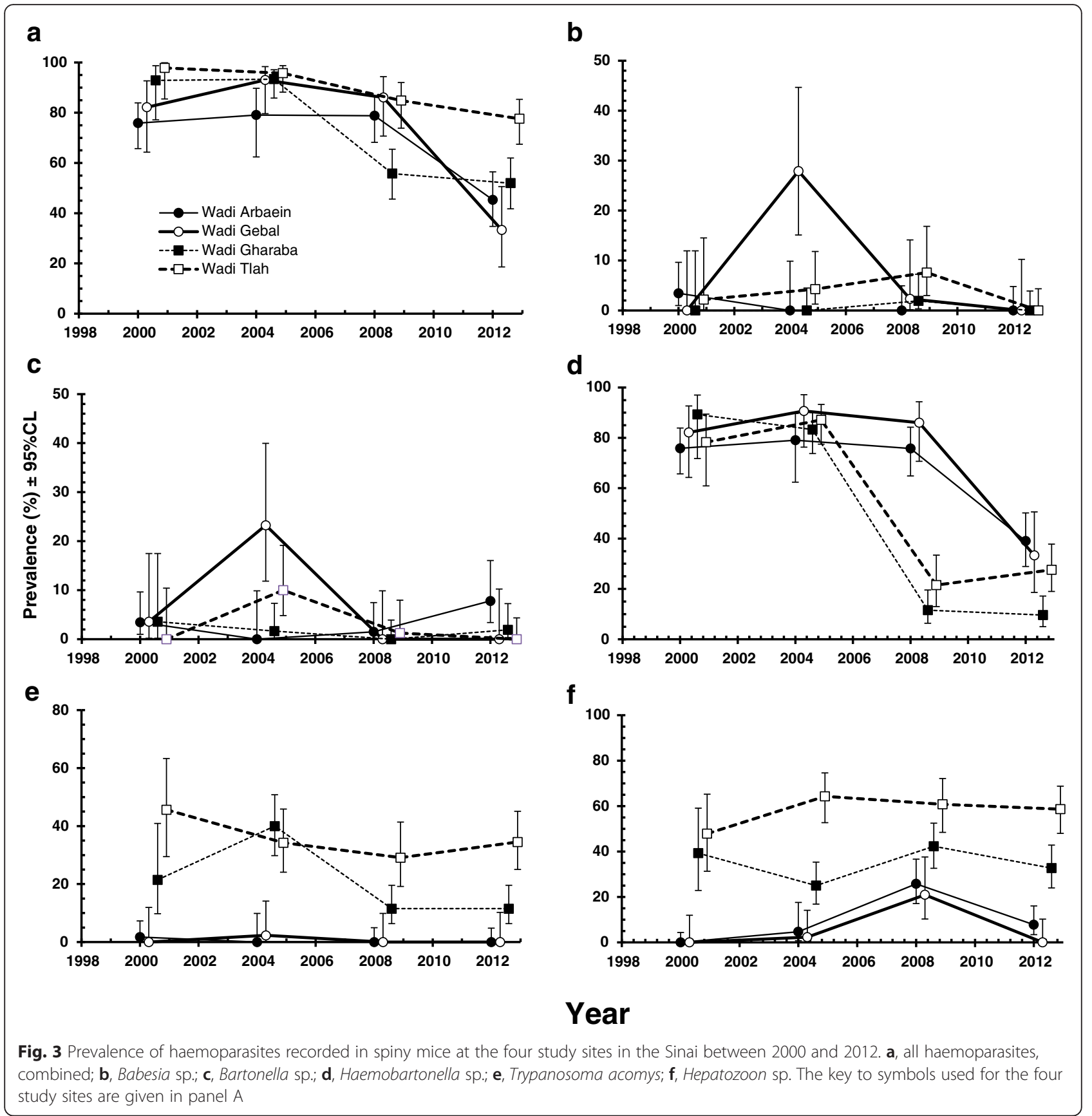

2004, twelve mice were infected, and one with 500 IC/200 FV, generating a mean for this site of $13.7 \pm 11.60$ for that year.

\section{Bartonella spp.}

The prevalence of Bartonella spp. was also very low (3.6 \%, 2.36-5.38). Prevalence varied significantly between years (Table 4; YEAR $\times$ INFECTION $\chi_{3}^{2}=19.0, P<0.001$ ) with a peak in 2004, mostly accounted for by high values among mice from Wadis Gebal and Tlah. Prevalence also rose in W. El Arbaein in 2012, but otherwise values were very low. There was no independent effect of SITE, but the significant SITE $\times$ YEAR $\times$ INFECTION interaction $\left(\chi_{9}^{2}=28.7, P=0.001\right)$ is illustrated in Fig. 3c. There were no independent effects of host sex or age, but there was a complex interaction involving these factors $($ SEX $\times$ SITE $\times$ AGE $\times$ INFECTION, $\left.\chi_{6}^{2}=19.6, P=0.003\right)$ which we did not explore further.

As with Babesia, quantitative analysis of abundance of Bartonella sp. was problematic because so few animals were infected (30/835). The overall mean abundance was $16.0 \pm 10.23 \mathrm{IC} / 200 \mathrm{FV}$, but this relatively 
Table 5 Abundance of haemoparasites by year, site, host sex and age class

\begin{tabular}{|c|c|c|c|c|c|c|c|c|c|c|c|c|}
\hline \multirow{3}{*}{$\overline{\text { Year }}$} & \multirow{2}{*}{\multicolumn{2}{|c|}{$\begin{array}{l}\text { Species richness } \\
\text { Mean } \pm \text { S.E.M. }\end{array}$}} & \multirow{2}{*}{\multicolumn{2}{|c|}{$\frac{\text { Babesia sp. }}{\text { Mean } \pm \text { S.E.M. }}$}} & \multirow{2}{*}{\multicolumn{2}{|c|}{$\frac{\text { Bartonella sp. }}{\text { Mean } \pm \text { S.E.M. }}$}} & \multirow{2}{*}{\multicolumn{2}{|c|}{$\begin{array}{l}\text { Haemobartonella sp. } \\
\text { Mean } \pm \text { S.E.M. }\end{array}$}} & \multirow{2}{*}{\multicolumn{2}{|c|}{$\frac{\text { Trypanosoma acomys }}{\text { Mean } \pm \text { S.E.M. }}$}} & \multirow{2}{*}{\multicolumn{2}{|c|}{$\frac{\text { Hepatozoon sp. }}{\text { Mean } \pm \text { S.E.M. }}$}} \\
\hline & & & & & & & & & & & & \\
\hline & & & & & & & & & & & & \\
\hline 2000 & 1.23 & 0.063 & 0.11 & 0.079 & 0.04 & 0.024 & 5.17 & 0.502 & 4.19 & 1.279 & 8.65 & 1.889 \\
\hline 2004 & 1.53 & 0.058 & 2.81 & 2.318 & 61.72 & 39.432 & 15.73 & 3.435 & 5.55 & 1.337 & 20.29 & 4.884 \\
\hline 2008 & 1.02 & 0.047 & 0.15 & 0.056 & 0.07 & 0.063 & 7.18 & 2.159 & 0.94 & 0.249 & 23.98 & 4.334 \\
\hline 2012 & 0.68 & 0.050 & 0 & 0 & 0.05 & 0.020 & 1.30 & 0.211 & 1.29 & 0.330 & 15.75 & 5.146 \\
\hline \multicolumn{13}{|l|}{ Site } \\
\hline Arbaein & 0.81 & 0.042 & 0.07 & 0.055 & 0.05 & 0.019 & 8.93 & 2.543 & 0.03 & 0.026 & 3.84 & 1.167 \\
\hline Gebal & 0.94 & 0.059 & 3.75 & 3.147 & 69.78 & 52.114 & 13.09 & 3.319 & 0.11 & 0.113 & 1.10 & 0.583 \\
\hline Gharaba & 1.03 & 0.060 & 0.03 & 0.026 & 0.06 & 0.036 & 3.28 & 0.571 & 4.65 & 1.438 & 15.59 & 2.629 \\
\hline Tlah & 1.52 & 0.056 & 0.17 & 0.06 & 8.89 & 7.929 & 5.76 & 1.797 & 5.77 & 0.925 & 43.14 & 6.835 \\
\hline \multicolumn{13}{|l|}{ Sex } \\
\hline Males & 1.08 & 0.043 & 0.25 & 0.073 & 5.72 & 5.394 & 7.68 & 1.820 & 1.55 & 0.262 & 16.21 & 2.741 \\
\hline Females & 1.12 & 0.039 & 1.22 & 1.079 & 24.23 & 17.889 & 7.29 & 1.352 & 3.88 & 0.766 & 19.30 & 3.433 \\
\hline \multicolumn{13}{|l|}{ Age } \\
\hline Class 1 & 0.95 & 0.057 & 0.38 & 0.122 & 63.32 & 44.54 & 8.98 & 3.046 & 1.66 & 0.419 & 2.25 & 0.772 \\
\hline Class 2 & 1.26 & 0.062 & 0.13 & 0.097 & 1.09 & 0.757 & 6.44 & 1.897 & 3.23 & 0.531 & 29.32 & 6.697 \\
\hline Class 3 & 1.09 & 0.039 & 1.32 & 1.183 & 2.58 & 2.365 & 7.32 & 1.375 & 3.18 & 0.806 & 19.00 & 2.664 \\
\hline
\end{tabular}

Significant main effects are highlighted in bold

high value was largely attributable to young mice from Wadis Gebal (mean $=258.0 \pm 191.4$ with values exceeding $1000 \mathrm{IC} / 200 \mathrm{FV}$ in three mice, maximum $=8000$ ) and Tlah $($ mean $=31.9 \pm 28.6$; maximum $=2000)$ in 2004 (Fig. $4 \mathrm{c}$ and Table 5). In marked contrast, in the remaining surveys the mean abundance values did not exceed $0.3 \mathrm{IC} / 200 \mathrm{FV}$ in the other wadis. Analysis was by non-parametric tests which showed that there was a hugely significant difference between surveys (Table 5; Kruskal-Wallis test with YEAR, $\left.X_{3}^{2}=20.9, P<0.001\right)$ and a weaker effect of SITE $\left(\chi_{3}^{2}=7.8, P=0.05\right)$. There was no significant difference between the sexes or between the age classes.

\section{Haemobartonella spp.}

The overall prevalence of Haemobartonella spp. was 57.8 \% (53.88-61.73). However, as can be seen in Table 4 and Fig. 3d, initially in the first two surveys prevalence was higher exceeding $75 \%$ in four wadis, but then prevalence fell markedly in two wadis in 2008 (Gharaba and Tlah), and the other two also by 2012 (YEAR $\times$ INFECTION, $\left.X_{3}^{2}=205.4, \quad P<0.001\right)$. The difference in prevalence between wadis was also significant (Table 4; SITE $\times$ INFECTION, $\chi_{3}^{2}=37.4, P<0.001$ ), with the highest overall value in W. Gebal and the lowest in W. Gharaba. Prevalence of this species was not affected by either host age or sex, but there was a significant interaction between all four factors and INFECTION $\left(\chi_{18}^{2}=35.9, P=0.007\right)$, suggesting some differences between age classes and the two sexes in particular data subsets (i.e. in particular years and sites) which we did not explore further.

The mean abundance for Haemobartonella sp. was $7.5 \pm 1.10 \mathrm{IC} / 200 \mathrm{FV}$. The best-fit model was a GLM with negative binomial errors (YEAR + SITE + AGE + YEAR $x$ SITE+ SITE $x$ AGE). There were highly significant main effects of YEAR $\left(L R_{3,826}=182.1, P<0.0001\right)$ and SITE $\left(L R_{3,826}=76.5, \mathrm{P}<0.0001\right)$ and these are summarised in Table 5. Abundance peaked in 2004 and was lowest in 2012, and peak abundance was detected in mice from W. Gebal, whilst the lowest value was from those from W. Gharaba. The highly significant interaction between SITE and YEAR $\left(L R_{9,811}=120.9, P<0.0001\right)$ is illustrated in Fig. 4d. This shows the dynamic changes that occurred between surveys, with peak abundance among mice from W. Gebal in three surveys $(2000,2008$ and 2012) but not in 2004 when peak abundance was among mice from W. El Arbaein. There was no main effect of host age $\left(L R_{2,826}=0.78, P=0.96\right)$, but there was a significant interaction between SITE and AGE $\left(L R_{6,811}=19.5, \quad P=0.0034\right)$ which is illustrated in Fig. 5b. As can be seen, the age-prevalence profiles were quite different among mice from each of the 4 wadis, although there was some similarity between those from Wadis Gharaba and Tlah where overall prevalence was lowest. Peak prevalence was observed in age class 1 mice in Wadi El Arbaein, in age class 3 in Wadi Gebal and in age class 2 in Wadis Gharbara and Tlah. An alternative 


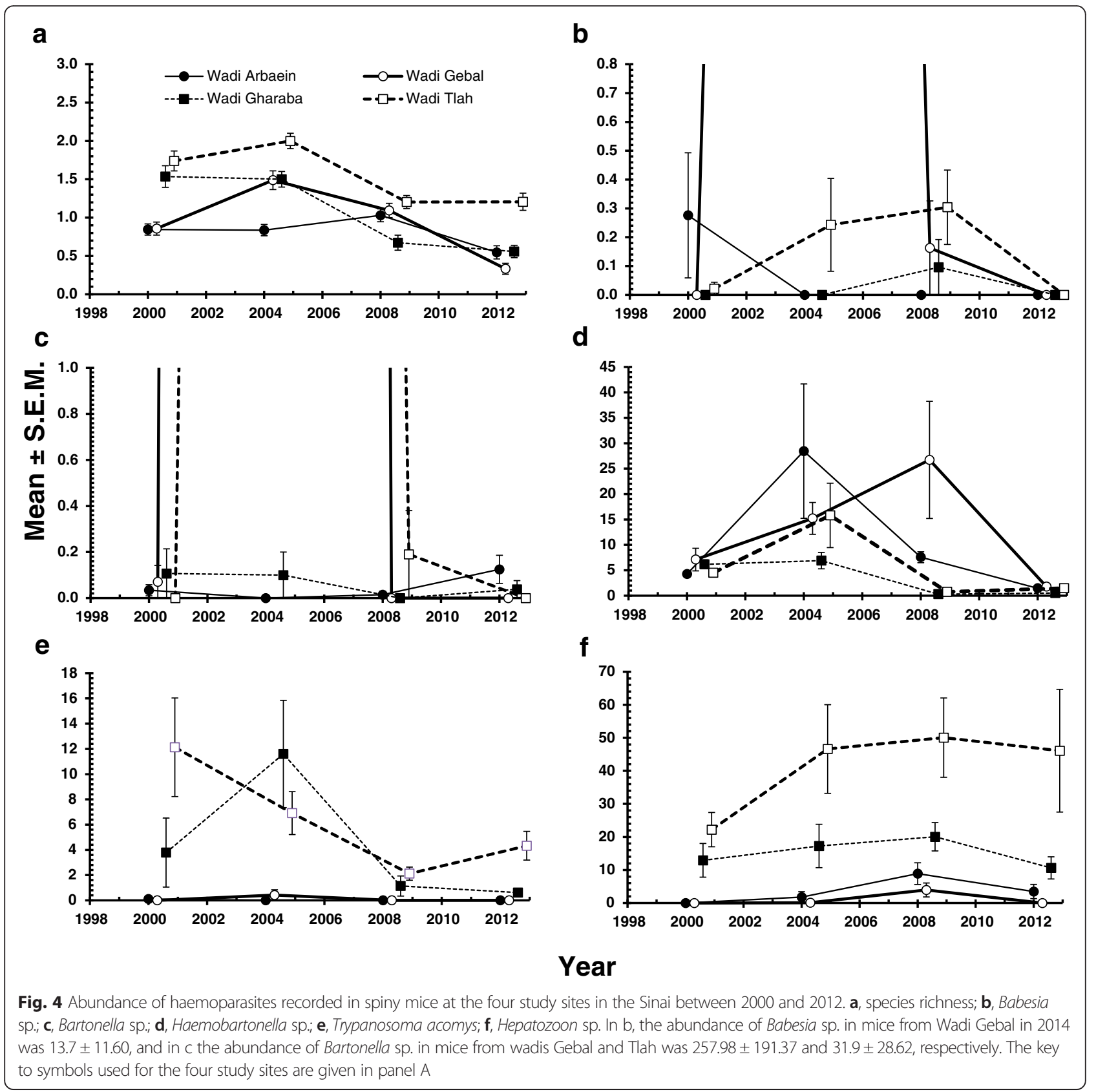

model based on log-transformed abundance and Gaussian errors generated much the same output $\left(R^{2}=0.34\right)$.

\section{Trypanosoma acomys}

The overall prevalence of $T$. acomys was $15.8 \%$ (13.09-18.92). Although prevalence changed significantly over the four surveys, peaking in 2004 (Table 4; YEAR $\times$ INFECTION, $\left.\chi_{3}^{2}=12.5, P=0.006\right)$, there was a huge difference between the wadis (SITE $\times$ INFECTION, $\chi_{3}^{2}=175.3$, $P<0.001$ ), with this species being largely confined to two of the four study sites in all four surveys (Gharaba and
Tlah; Fig. 3e). There was no difference in prevalence between the two sexes, but there was a significant difference between age classes (AGE $\times$ INFECTION, $\chi_{2}^{2}=26.8$, $P<0.001$ ). Prevalence was highest in age class 2 (Table 4 ), and then dropped by more than $50 \%$ in the oldest age class. There were no significant confounding interactions in this case.

Since this parasite was largely confined to just two of the four wadis, we recalculated the effect of age on prevalence restricting the data to mice from wadis Gharba and Gebal, and this is shown in Fig. 6a. Prevalence in age class 2 spiny 


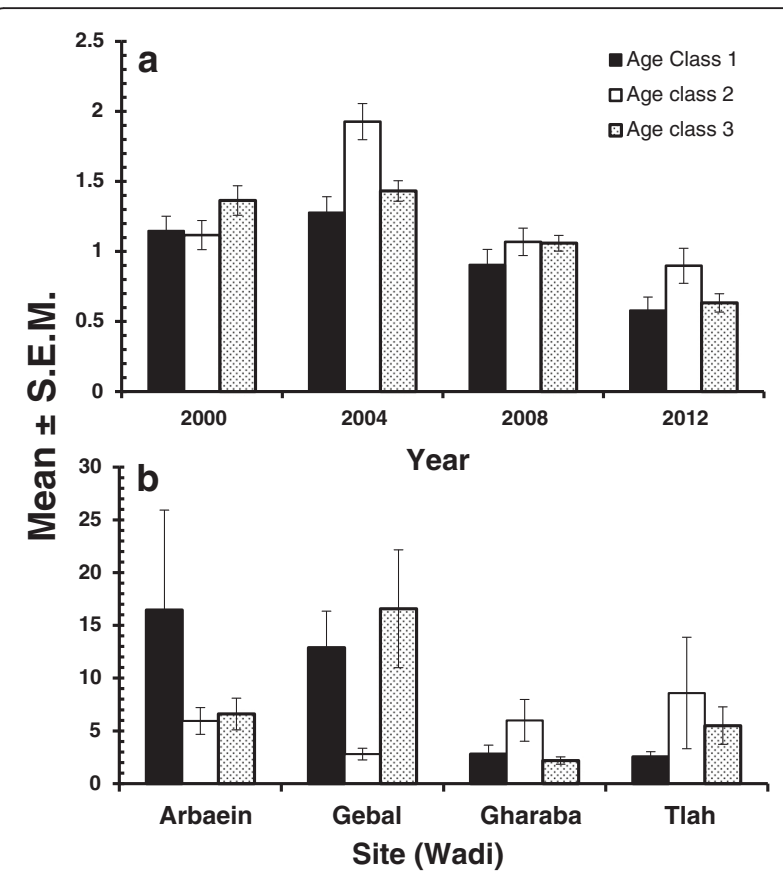

Fig. $\mathbf{5}$ Variation in haemoparasites in spiny mice sampled by age class. a, species richness by year of survey; $\mathbf{b}$, abundance of Haemobartonella sp. by site

mice was now 46.4\% (38.75-54.16), falling to $18.9 \%$ (15.57-22.85) among the oldest mice, a reduction of $59.2 \%$.

The mean abundance of $T$. acomys was $2.85 \pm 0.443$. Parametric models based on raw data with Gaussian or negative binomial errors, and $\log _{10}(\mathrm{X}+1)$ transformed data with Gaussian errors all failed to generate acceptable distributions of residuals. However analysis by 1 -way nonparametric tests identified a marked effect of SITE (Table 5; Kruskal-Wallis test, $\chi_{3}^{2}=141.5, P<0.001$ ) mean abundance of trypanosomes being higher in mice from W. Gharaba and Tlah. There were also significant changes in abundance between the 4 surveys (Kruskal-Wallis test on effect of YEAR $\chi_{3}^{2}=16.1, P=0.001$ ) with mean abundance higher in the first two surveys compared with the latter two. Abundance also increased with host age, especially between the youngest mice and age class 2, and then fell marginally in the oldest mice (Kruskal-Wallis test on effect of AGE $\left.X_{2}^{2}=26.8, P<0.001\right)$. There was no significant difference in abundance between the sexes. Changes of abundance over time in the 4 wadis are illustrated in Fig. 4e, where it can be seen clearly that mean abundance was consistently higher among mice from Wadis Gharaba and Tlah compare to those from Wadis El Arbaein and Gebal.

\section{Hepatozoon sp.}

The prevalence of this species was $29.7 \%$ (26.17-33.47). As with T. acomys, Hepatozoon sp. was largely confined to the same two wadis (Gharaba and Tlah), and not surprisingly there was a huge SITE effect (SITE $\times$ INFECTION, $\left.X_{3}^{2}=198.6, P<0.001\right)$. Prevalence also varied between the surveys $\left(\right.$ YEAR $\times$ INFECTION, $\left.\chi_{3}^{2}=20.2, P<0.001\right)$ and differently among the mice from the four wadis (Fig. 3f; SITE $\times$ YEAR $\times$ INFECTION $\left., \chi_{9}^{2}=36.1, P<0.001\right)$. There was no effect of host sex, but age affected prevalence significantly (Table $4 ; \chi_{2}^{2}=56.7, P<0.001$ ), and the precise effect of age on prevalence varied between the surveys (Not illustrated, AGE $\times$ YEAR $\times$ INFECTION, $\left.X_{6}^{2}=17.7, P=0.007\right)$. Very few of the youngest mice were infected, but then prevalence increased and stabilized in mature and older individuals some 3-4 times higher (Table 4). However, since this species, like $T$. acomys, was largely confined to mice from Wadis Gharaba and Tlah, the analysis was repeated excluding individuals from the other two wadis and this is illustrated in Fig. 6b. Prevalence was still very low among the youngest mice (16.1\% [7.95-28.36]), but rose to over $55 \%$ among age classes 2 and 3.

The mean abundance of this species was $17.9 \pm 2.26$. Parametric models based on raw data with Gaussian or negative binomial errors, and $\log _{10}(X+1)$ transformed data with Gaussian errors all failed to generate acceptable distributions of residuals. Analysis by 1-way non-parametric tests identified a marked effect of SITE (Table 5; Kruskal-Wallis test, $\left.\chi_{3}^{2}=190.8, P<0.001\right)$, mean abundance of Hepatozoon sp. being highest in W. Tlah and lowest in W. Gebal. There were also significant changes in abundance between the 4 surveys with peak abundance detected in 2008 (KruskalWallis test on effect of YEAR $\chi_{3}^{2}=21.2, P=0.001$ ). As with $T$. acomys abundance was lowest in the youngest mice, higher among age class 2 before falling in age class 3 (Kruskal-Wallis test on effect of AGE $\chi_{2}^{2}=51.1, P<0.001$ ). There was no significant difference in abundance between the sexes. Changes of abundance over time in the four wadis are illustrated in Fig. 4f, where the consistently high abundance among mice from W. Tlah can be seen. This is followed by a consistent intermediate level of abundance among mice from W. Gharaba and much lower abundance among animals from the remaining two wadis, although there was a small peak in abundance in 2008 among mice from the latter two sites.

\section{Discussion}

\section{Molecular identification of parasites}

Molecular techniques were used for the identification of parasite species/genotype and for a preliminary study of the diversity of parasites among the four semi-isolated populations of spiny mice. Analyses of the sequences that we obtained did not allow exact identification of species (no $100 \%$ sequence homology was found in the GenBank database) of Bartonella, Trypanosoma or Hepatozoon as to-date, excepting our own depositions, 


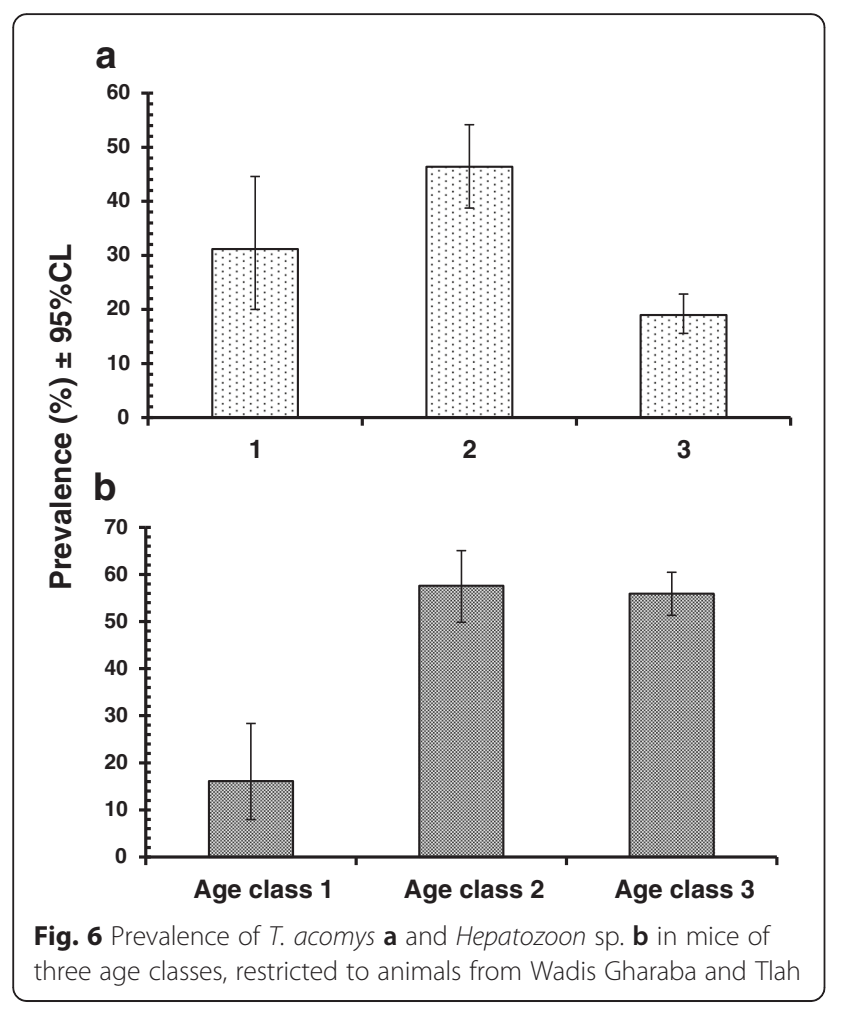

no data on the haemoparasites specific to $A$. dimidiatus have been deposited. The closest match was for Bartonella, as our sequence was $>99 \%$ similar to B. acomydis, the species described from the golden spiny mouse, $A$. russatus [35]. As Bartonella species/genotypes show some host-specificity, further study on the Bartonella from $A$. dimidiatus is needed to clarify with certainty the identity of the parasite in the spiny mice in our study sites. Interestingly, in our study more Bartonella-positive mice were detected by conventional microscopy of blood smears, but only one PCR product was obtained with the primers that we used. In Inoue et al. [35], the study referred to above, the overall prevalence of Bartonella in A. dimidiatus imported from Egypt to Japan was $9.7 \%$, relatively low as in our study, but in three isolates B. elizabethae was identified (100 \% homology with GenBank reference sequences), a species that is pathogenic for humans. Therefore, it is still possible that other species/ strains of Bartonella may be found in the future in spiny mice from our S. Sinai study sites.

There is only one species of Trypanosoma described from spiny mice, $T$. acomys $[37,38]$, but no reference sequences for $18 \mathrm{~S}$ rDNA of this species are available in GenBank. However, almost no diversity was observed in the 45 Trypanosoma sequences that we compared and this supports the identification of our isolates as the hostspecific T. acomys. Interestingly, one of our sequences was different (variant B), but still most closely related to our dominant variant- variant A of T. acomys. T. acomys was found in mice from two quite distant wadis (W. Tlah and W. Gharaba) which despite the distance between them are connected, W. Gharaba being located at the extreme north end of the continuous valley system leading away from St. Katherine [9], and there was no detectable diversity between the isolates from these two wadis.

The genotyping of Hepatozoon isolates from the two Acomys species revealed the presence of two variants, A and $\mathrm{B}$, and neither of these could be identified to species level through comparison with data in GenBank (at best homology was 96-97 \% with known Hepatozoon species). Only one species of Hepatozoon has been described from Acomys spp. - H. acomys (Mohammed and Saound 1972, following [39]) and generally the systematics of this genus are still poorly developed $[36,39]$. The majority of identified Hepatozoon infections from different groups of animals, including amphibians, reptiles and mammals, are reported simply as 'Hepatozoon sp.' However, even among the conserved $18 \mathrm{~S}$ rDNA sequences of those Hepatozoon spp. isolates that have been deposited, there are significant differences (Fig. 1) and there is an urgent need to name the different genotypes of Hepatozoon that are known to be associated with certain host species. Only one detailed description of Hepatozoon from Egyptian rodents is currently available- $H$. balfouri in J. jaculus and J. orientalis [40]. However, the gamonts of this species were found only in erythrocytes, and never in leucocytes, in contrast to the Hepatoozon that we observed in A. dimidiatus. Moreover, a recent study of Hepatozoon from jerboas revealed sequences that were quite different to our own isolates (Fig. 1; [36]), supporting the existence of a different Hepatozoon species in A. dimidiatus. Interestingly, our variant B of Hepatozoon was found only in one of the two Acomys species, A. russatus, which is consistent with the idea of host-specificity among parasites in this genus.

\section{Long-term ecological study}

Our data show that the haemoparasite communities varied markedly between the four subpopulations of spiny mice living in isolated wadis and displayed long-term trends, most likely associated with the increasing aridity of the environment during the years of our surveys. The haemoparasite communities of $A$. dimidiatus were dynamic, with only some species showing stability across the 12-year-long period. As predicted, external factors (site and year of study) had a much greater influence on the haemoparasite community than the intrinsic factors that we took into account in our analyses (host age or sex).

Long-term dynamic changes of haemoparasites were observed in prevalence, abundance and in mean species richness, as reflected in the spatio-temporal patterns/ trends illustrated in Figs. 3 and 4 (the year $\mathrm{x}$ site interactions). While the prevalence of haemoparasites was 
relatively high and stable during the first two surveys, in 2000 and 2004, there was a $50 \%$ reduction by the last survey in 2012, and this pattern of declining prevalence was observed clearly among the spiny mice in 3 of the 4 wadis in our study (W. El Arbaein, W. Gebal, W. Gharaba), with only slightly lower values for mice from W. Tlah. Mean species richness was the highest in 2004 and then decreased by more than $50 \%$ to 2012 . Both of these two parameters (prevalence and mean species richness) were significantly reduced in 2008 and then in 2012, compared with the earlier surveys. The fall in value of both parameters may have two non-mutually exclusive explanations- an exceptionally high prevalence of two 'rare' pathogens, Babesia and Bartonella sp. in 2004, exceeding 20-30 \% in W. Gebal, and the marked decrease in Haemobartonella sp., in 2008 in W. Tlah and Gharaba, and then in 2012 in W. El Arbaein and Gebal. Although overall prevalence of $T$. acomys was generally stable over the 12-year-long period, the greatest stability was observed in W. Tlah while in W. Gharaba prevalence of Trypanosoma followed the general trend in the prevalence of other haemoparasites - a significant, albeit relatively small, reduction during last two surveys, contributing to an overall drop in haemoparasite prevalence and mean species richness. Interestingly, even for this 'stable' parasite, the abundance and intensity of infection were much lower in 2008 and 2012 in both W. Tlah and Gharaba, compared to the first two surveys. An opposite trend was found for H. acomys - the only parasite species displaying an increase in prevalence in 2008 and a spread to new sites.

This fall in the value of three parameters must reflect a drop in transmission of these vector-borne parasites. There have been severe fluctuations in the weather in the Sinai over the past decade (2002-2010). Since 2002 there has been a severe drought with very little $(<50 \mathrm{~mm})$ or no rain every year until March 2010 and therefore one underlying explanation could be the marked decrease in water availability, first noted during the expedition in 2008. This was the first expedition during which we observed a lack of water pipes that are usually employed to deliver water to Bedouins' gardens situated at higher altitudes in the wadis, the lack of water in wells located in the wadis, the abandonment of several gardens in W. Gebal and Gharaba, resulting not only in a lack of ground-cover plants and vegetables but also in desiccation of trees. This drought was broken in May 2010 when there was heavy rainfall. 2011 was again extraordinarily wet, with heavy rainfall and snow in the winter and spring, while 2012 had very little rainfall and was colder than normal. Although almost the wettest place in Egypt (second only to the Mediterranean northwestern coast), according to the best (patchy) data we have, the mountains of South Sinai received only an average of $42.5 \mathrm{~mm}$ per year precipitation between 1970 and 1994, and substantially less $(15.5 \mathrm{~mm})$ between 2001 and 2009 (data courtesy of the St Katherine Protectorate Management Unit) [28]. These weather conditions have probably caused the marked changes recorded in a parallel long-term study on the Sinai thyme (Thymus decussatus) population. Between 2002 and 2010, the number of thyme plants in Farsh Shoeib near St Katherine fell from 1208 to 669 , i.e. $44.6 \%$ of the plants disappeared (assumed to have died). Between 2002 and 2010, the condition of plants deteriorated decreasing from $53 \%$ to $25 \%$; one-third of the surviving plants were $<10 \%$ green [28].

Most likely as a result of these local climatic changes, a greater effort had to be made to catch representative numbers of mice for our study - reflected in the significantly higher number of trapping hours in 2008 and 2012, in comparison to 2000 and 2004. Although we are not able to conclude with any degree of certainty if rodent population sizes have actually fallen because of this significant change in their habitats (reduction in water availability and in the acreage of Bedouin gardens), we may nevertheless be certain that at least the population densities of the mouse subpopulations were lower in the latter two surveys. This may have affected the transmission of parasites with consequent lower prevalence - both density-dependent or frequency-dependent, as established convincingly in the long-term studies on cowpox virus transmission in field voles, Microtus agrestis, in Kielder forest, UK (reviewed in [3]). Changes in the abiotic factors in the study sites affected not only the host populations but also could have had a direct negative impact on the survival of parasite vectors such as juvenile fleas and ticks, contributing also to overall lower transmission rates.

Generally, the changes observed in the haemoparasite communities of spiny mice in the Sinai were much more pronounced and more diverse than the patterns/trends observed in our other studies on haemoparasites in common and bank voles from central Europe (Poland) $[4,19,20]$. This marked dynamic may reflect a more fragile structure of parasite communities in the hyper-arid environment in Egypt, in comparison to the relatively more predictable abiotic conditions in woodland habitats in central and northern Europe, which show marked seasonal changes but an annual sequence of changes that varies little from year to year.

Although we observed significant temporal changes, nevertheless the site of sampling of the mouse population was always the main factor influencing haemoparasite community structure and many of the differences between the wadis that we observed in 2000 [10] were maintained during the subsequent 12-year-long period of monitoring. Subpopulations from wadis Tlah and Gharaba constituted the main hosts for T. acomys and Hepatozoon sp., and 
spread of the latter species to other mouse populations observed in 2008 was only partially successful. It is apparent therefore that ideal conditions for maintaining the host-vector-parasite relationship exist only in these two sites/habitats. As we reported in our earlier paper [10], fleas (Parapulex chephrensis), the most likely vectors of Trypanosoma [41] and Hepatoozon, were found mostly on mice from Wadis Tlah and Gharaba (unpublished observations for 2012 confirm the published data from 2000, reported in [10]). In 2000 no fleas were found on mice from W. Gebal, and only two mice from W. El Arbaein were found with fleas. The overall prevalence of T. acomys among mice with its likely flea vector was $44.8 \%$ compared with just $12 \%$ among mice without fleas and there was a weak but statistically significant overall association between prevalence of $T$. acomys and flea infestation [10]. Similarly, in 2000 the prevalence of Hepatozoon sp. among mice with fleas was $41.4 \%$, in contrast to $16.8 \%$ among mice without fleas. However, when the site, sex and age effects were controlled for, no significant association was evident between these taxa.

Comparing haemoparasite communities between the host subpopulations from the four wadis, spiny mice from W. Tlah consistently showed the highest mean species richness, total species richness and the highest prevalence of all haemoparasites. This site experienced also the least change in habitat structure over the 12-year period and the lowest loss of arable land. Wadi Tlah consists of a deep, narrow valley with steep cliffs on both sides, with ample shaded areas, well-maintained gardens and few apparent signs of aridification because it drains most of the high-mountain region, so any rainfall will percolate through it. The prevalence of $T$. acomys underwent almost no change in mice from this wadi. In contrast, by the end of our study period mice from the high-altitude W. Gebal showed the lowest mean species richness and lowest prevalence of all haemoparasites. This is in agreement with previous studies on haemoparasites from $A$. dimidiatus from this wadi, and is also consistent with studies on intestinal micro- and macroparasites and ectoparasites $[9,10]$. Mice from W. Gebal have consistently revealed an impoverished parasite fauna, lacking both the flea $P$. chephrensis and T. acomys, in addition to the absence of the dominant nematode Protospirura muricola [9]. However, this wadi constituted the main focus for the transmission of a novel Babesia species- $B$. behnkei- discovered in Wagner's gerbil $D$. dasyurus in 2004 and recently described [42]. This high-altitude wadi experiences the most extreme abiotic conditions and greatest degree of aridification/desertification: by 2008 about half of Bedouins' gardens in this wadi had been abandoned and in 2012 even the remaining trees and bushes were extensively desiccated and damaged by grazing feral donkeys. In contrast, mice from the low-level
W. Gharaba, which has greater exposure to direct sunlight and is considerably warmer than the other three wadis, were heavily infected with $P$. muricola, $P$. chephrensis and $T$. acomys $[9,10]$. As with W. Gebal, this site has experienced severe shortage of water with resulting increased aridity, and this change in climatic conditions is reflected in reduced prevalence and abundance of both Haemobartonella sp. and T. acomys, but interestingly not Hepatozoon. Wadi El Arbaein is the site that is most affected by human activities, with a large town (St Katherine) localized at its mouth, and it experiences extensive exposure to livestock, mainly goats and camels, but also cats and dogs. This is also the wadi with the highest tourist activity. During the 12-year-long period the town has grown and developed (i.e. construction of new paved roads, lighting on the streets) but has also been affected by drought, the level of ground water having fallen alarmingly over this period (from $7 \mathrm{~m}$ to about 25 $m$ in Fox Camp). The construction of new water storage tanks and water pipes for the provision of water for the city from the coast had not been successfully completed by 2012. Perhaps not surprisingly therefore, the mice from W. El Arbaein showed the lowest prevalence of haemoparasites in the early surveys and a variable pattern of haemoparasite species richness and prevalence, generally as in the mice from W. Gebal. Interestingly, as in the mice from W. Gebal, $H$. acomys was introduced to the mice in this wadi in 2004 and then increased in prevalence and persisted through to 2012, creating a third location for the occurrence of this parasite among spiny mice in our study sites.

As we had predicted, host sex has no detectable influence on the haemoparasite community, and this is consistent with many earlier studies [3, 22-24], including our work in Egypt and Poland $[4,10,20,21]$. However, there were two contrasting patterns in relation to host age. For Babesia and Haemobartonella, the highest prevalence or abundance were observed in young animals, but for Trypanosoma and Hepatozoon the highest infection parameters were from adults (class 2 or 3). The former pattern of increasing likelihood of carrying infection with increasing host age is consistent with the idea that the longer the mouse lives, the higher the probability of being infested by an infected vector and hence of contracting the infection. Most of the parasites identified in this study typically cause long subclinical infections in their natural hosts [37, 42], and thus the proportion of animal carrying infection increases with host age, peaking among the older animals. The latter pattern of peak prevalence in young animals, as observed in the case of T. acomys and Hepatozoon sp., can have two explanations. One possibility is vertical transmission resulting in congenital or neonatal (i.e. transmitted by nest ectoparasites) infection and this combined with the high susceptibility of young naïve individuals to infections, and 
followed by acquired immunity reducing prevalence among the older sectors of the population. Vertical transmission and congenital infections have been confirmed for Babesia spp. [43, 44], Hepatozoon balfouri [40] and Haemobartonella (Mycoplasma) [45].

Rodent trypanosomes are known to generate potent sterilizing immunity. Thus the declining prevalence of $T$. acomys in the oldest age class, was not unexpected given that this species probably generates life-long immunity just like T. lewisi and T. musculi to which it is closely related. The long patent period explains the high prevalence of infection with T. acomys in mice of age class 2 , and the decline in the oldest mice (age class 3 ) suggests either the action of some form of immunity in laterlife or selective mortality of infected older mice. An immune response certainly occurs in $T$. lewisi and $T$. musculi, and is suggested by the data of Abdallah et al. [37] for T. acomys, which show clearance from peripheral blood after 150 days, although a mechanism for this has not yet been identified.

\section{Conclusions}

Haemoparasite communities varied markedly between four subpopulations of spiny mice living in isolated wadis and displayed long-term trends, most likely associated with a changing environment driven by decade-long drought. As predicted, external factors (site and year of study) had a much greater influence on parasite communities than intrinsic factors (host age or sex).

\section{Additional files}

Additional file 1: Nucleotide sequences and annealing temperature of the primers used for polymerase chain reaction (PCR). (DOCX $17 \mathrm{~kb}$ )

Additional file 2: Alignment of two $18 \mathrm{~S}$ rDNA Hepatozoon variants with the two most similar sequences of Hepatozoon from the GenBank database. (DOCX $74 \mathrm{~kb}$ )

Additional file 3: Alignment of two 18S rDNA Trypanosoma variants with the most similar sequences of Trypanosoma from the GenBank database. (DOCX $104 \mathrm{~kb}$ )

\section{Competing interests}

The authors declare that they have no competing interests.

\section{Authors' contributions}

MA and RWF performed microscopical, molecular and phylogenetic studies, $A B$ designed the study and supervised laboratory and field analyses, MB and AK participated in detection of haemoparasites, JMB, FG and SZ organized and supervised field work in Sinai. EJM, JBB and EMEM performed the laboratory and field studies and drafted the manuscript. All authors read and approved the final version of the manuscript.

\section{Acknowledgements}

The molecular study of haemoparasites and Polish staff expedition to Egypt in 2012 were funded by the National Science Center (NCN), Poland, grant OPUS 2011/03/B/NZ6/02090(AB) and by the Ministry of Science and Higher Education through the Faculty of Biology, University of Warsaw intramural grant DSM number 140000/501/86-110101 (MA). We are grateful to the University of Nottingham for providing travel expenses and to the British Council, Cairo, Egypt, for financial support of this study. Anna Bajer's expedition in 2008 was supported financially by KBN-BC Young Scientist Program no. WAW/342/06. We are grateful to all the staff of the Environment Research Centre of Suez Canal University and our Bedouin hosts from Fox Camp at St Katherine for their support and warm hospitality during our stay. We thank Mohammed Shaker and Mohamed Qotb for permission to work in the St Katherine Protectorate, the staff at the Rangers office for providing vehicles and drivers, and skilled Bedouin guides, enabling access to some of the remote locations and for their company and support on each of the expeditions. Mustafa Rashid El-Rafaei's skills in trapping rodents are also gratefully acknowledged.

\section{Author details}

${ }^{1}$ Department of Parasitology, Institute of Zoology, Faculty of Biology, University of Warsaw, 1 Miecznikowa Street, 02-096, Warsaw, Poland. ²Desert Research Center, Cairo, Egypt. ${ }^{3}$ Department of Forest Phytopathology, Faculty of Forestry, Poznań University of Life Sciences, Poznań, Poland. ${ }^{4}$ Department of Zoology, Suez Canal University, Ismailia, Egypt. ${ }^{5}$ Faculty of Medicine \& Health Sciences, School of Biology, University of Nottingham, Nottingham, UK. ${ }^{6}$ Department of Ecology, Institute of Zoology, Faculty of Biology, University of Warsaw, 1 Miecznikowa Street, 02-096, Warsaw, Poland.

Received: 23 October 2015 Accepted: 23 March 2016

Published online: 08 April 2016

\section{References}

1. Bujalska G, Hansson L. Bank vole biology: recent advances in the population biology of a model species. Pol J Ecol. 2000;48:5-7.

2. Flowerdew JR, Gurnell J, Gipps JHW. The ecology of woodland rodents: bank voles and wood mice: the proceedings of a symposium held at the Zoological Society of London on 23rd and 24th of November 1984. 1985.

3. Turner AK, Beldomenico PM, Bown K, et al. Host-parasite biology in the real world: the field voles of Kielder. Parasitology. 2014;141:997-1017.

4. Bajer A, Welc-Falęciak R, Bednarska M, et al. Long-term spatiotemporal stability and dynamic changes in the haemoparasite community of bank voles (Myodes glareolus) in NE Poland. Microb Ecol. 2014;68:196-211. doi:10. 1007/s00248-014-0390-9.

5. Bajer A. Between-year variation and spatial dynamics of Cryptosporidium spp. and Giardia spp. infections in naturally infected rodent populations. Parasitology. 2008;135:1629-49. doi:10.1017/S0031182008004952.

6. Behnke JM, Bajer A, Harris PD, et al. Temporal and between-site variation in helminth communities of bank voles (Myodes glareolus) from N.E. Poland. 1. Regional fauna and component community levels. Parasitology. 2008;135: 985-97. doi:10.1017/S0031182008004393.

7. Behnke JM, Bajer A, Harris PD, et al. Temporal and between-site variation in helminth communities of bank voles (Myodes glareolus) from N.E. Poland. 2. The infracommunity level. Parasitology. 2008;135:999-1018. doi:10.1017/ S0031182008004484

8. Lello J, Hussell T. Functional group/guild modelling of inter-specific pathogen interactions: A potential tool for predicting the consequences of co-infection. Parasitology. 2008;135:825-39. doi:10.1017/S0031182008000383.

9. Behnke JM, Harris PD, Bajer A, et al. Variation in the helminth community structure in spiny mice (Acomys dimidiatus) from four montane wadis in the St Katherine region of the Sinai Peninsula in Egypt. Parasitology. 2004;129: 379-98. doi:10.1017/S003118200400558X.

10. Bajer A, Harris PD, Behnke JM, et al. Local variation of haemoparasites and arthropod vectors, and intestinal protozoans in spiny mice (Acomys dimidiatus) from four montane wadis in the St Katherine Protectorate, Sinai, Egypt. J Zool. 2006;270:9-24. doi:10.1111/j.1469-7998.2006.00089.x.

11. Zalat S, Semida F, Gilbert F, et al. Spatial variation in the biodiversity of Bedouin gardens in the St Katherine Protecorate, South Sinai, Egypt. Egypt J Biol. 2001;3:147-55.

12. Thompson JN. The geographic mosaic of coevolution. University of Chicago Press; 2005

13. Namangala B, Inoue N, Sugimoto C. Preliminary studies on the effects of orally-administered Transforming Growth Factor-beta on protozoan diseases in mice. Jpn J Vet Res. 2009;57:101-8.

14. Oz HS, Hughes WT. Acute fulminating babesiosis in hamsters infected with Babesia microti. Int J Parasitol. 1996;26:667-70. doi:10.1016/00207519(96)00022-7. 
15. Beldomenico PM, Telfer S, Gebert S, et al. The vicious circle and infection intensity: The case of Trypanosoma microti in field vole populations. Epidemicsjepidem. 2009;1:162-7. doi:10.1016/2009.05.002.

16. Geerts S, Osaer S, Goossens B, Faye D. Trypanotolerance in small ruminants of sub-Saharan Africa. Trends Parasitol. 2009;25:132-8. doi:10.1016/j.pt.2008. 12.004.

17. Goossens B, Osaer S, Ndao M, et al. The susceptibility of Djallonké and Djallonké-Sahelian crossbred sheep to Trypanosoma congolense and helminth infection under different diet levels. Vet Parasitol. 1999;85:25-41. doi:10.1016/S0304-4017(99)00087-4.

18. Kloch A, Baran K, Buczek M, et al. MHC influences infection with parasites and winter survival in the root vole Microtus oeconomus. Evol Ecol. 2012;27: 635-53. doi:10.1007/s10682-012-9611-1.

19. Bajer A, Pawelczyk A, Behnke J, et al. Factors affecting the component community structure of haemoparasites in bank voles (Clethrionomys glareolus) from the Mazury Lake District region of Poland. Parasitology. 2001; 122:43-54. doi:10.1017/S0031182000007058.

20. Pawelczyk A, Bajer A, Behnke JM, et al. Factors affecting the component community structure of haemoparasites in common voles (Microtus arvalis) from the Mazury Lake District region of Poland. Parasitol Res. 2004;92:27084. doi:10.1007/s00436-003-1040-1.

21. Welc-Falęciak R, Bajer A, Behnke JM, Siński E. The ecology of Bartonella spp. infections in two rodent communities in the Mazury Lake District region of Poland. Parasitology. 2010;137:1069-77. doi:10.1017/S0031182009992058.

22. Healing TD. Infections with blood parasites in the small British rodents Apodemus sylvaticus, Clethrionomys glareolus and Microtus agrestis. Parasitology. 1981;83:179-89.

23. Sebek Z. Blood parasites of small wild mammals in Czechoslovakia. Folia Parasitol (Praha). 1974;22:11-20.

24. Turner CMR. Seasonal and age distributions of Babesia, Hepatozoon Trypanosoma and Grahamella species in Clethrionomys glareolus and Apodemus sylvaticus populations. Parasitology. 1986;93:279-89.

25. Smith A, Telfer S, Burthe $S$, et al. Trypanosomes, fleas and field voles: ecological dynamics of a host-vector-parasite interaction. Parasitology. 2005;131:355-65. doi:10.1017/S0031182005007766.

26. Issar AS, Adar E. Progressive development of water resources in the Middle East for sustainable water supply in a period of climate change. Philos Trans $R$ Soc Lond Math Phys Eng Sci. 2010:368:5339-50. doi:10.1098/rsta.2010.0184.

27. Issar AS, Ginat $H$, Zohar M. Shifts from deserted to inhabited terrain in the arid part of the Middle East, a function of climate changes. J Arid Environ. 2012;86:5-11. doi:10.1016/j.jaridenv.2011.09.013.

28. Thompson K, Gilbert F. Spatiotemporal variation in the endangered Thymus decussatus in a hyper-arid environment. J Plant Ecol. 2015;8:79-90. doi:10.1093/jpe/rtu004.

29. Average precipitation in depth (mm per year) | Data | Table. http://data. worldbank.org/indicator/AG.LND.PRCP.MM. Accessed 10 Sep 2015

30. Paziewska A, Harris PD, Zwolińska L, et al. Recombination within and between species of the alpha proteobacterium Bartonella infecting rodents. Microb Ecol. 2010:61:134-45. doi:10.1007/s00248-010-9735-1.

31. Inokuma H, Okuda M, Ohno K, et al. Analysis of the $18 \mathrm{~S}$ rRNA gene sequence of a Hepatozoon detected in two Japanese dogs. Vet Parasitol. 2002;106:265-71. doi:10.1016/S0304-4017(02)00065-1.

32. Tamura K, Stecher G, Peterson D, et al. MEGA6: Molecular Evolutionary Genetics Analysis Version 6.0. Mol Biol Evol. 2013;30:2725-9. doi:10.1093/molbev/mst197.

33. Noyes HA, Stevens JR, Teixeira M, et al. A nested PCR for the ssrRNA gene detects Trypanosoma binneyi in the platypus and Trypanosoma sp. in wombats and kangaroos in Australia. Int J Parasitol. 1999:29:331-9.

34. Rohlf FJ, Sokal RR. Statistical tables. Macmillan; 1995

35. Inoue $\mathrm{K}$, Maruyama $\mathrm{S}$, Kabeya $\mathrm{H}$, et al. Exotic small mammals as potential reservoirs of zoonotic Bartonella spp. Emerg Infect Dis. 2009;15:526-32. doi: 10.3201/eid1504.081223.

36. Maia JP, Álvares F, Boratyński Z, et al. Molecular assessment of Hepatozoon (Apicomplexa: Adeleorina) infections in wild canids and rodents from north Africa, with implications for transmission dynamics across taxonomic groups. J Wildl Dis. 2014;50:837-48. doi:10.7589/2013-10-280.

37. Abdallah MA, Abdel-Hafez SK, Al-Yaman FM. Trypanosoma acomys (Wenyon 1909): reproductive forms and course of parasitemia in the natural host Acomys cahirinus (Desmarest, 1819). Parasitol Res. 1989:75:439-43. doi:10.1007/BF00930969.
38. Maraghi S, Wallbanks KR, Molyneux DH, Abdel-Hafez SK. In vitro cultivation of Trypanosoma acomys: production of insect stages and bloodstream forms. Parasitol Res. 1995;81:672-6. doi:10.1007/BF00931845.

39. Smith TG. The genus Hepatozoon (Apicomplexa: Adeleina). J Parasitol. 1996; 82:565-85. doi:10.2307/3283781.

40. Hoogstraal $\mathrm{H}$. The life cycle and Incidence of Hepatozoon balfouri (Laveran, 1905) in Egyptian jerboas (Jaculus spp.) and mites (Haemolaelaps aegyptius Keegan, 1956). J Protozool. 1961;8:231-48. doi:10.1111/j.1550-7408.1961.tb01209.x.

41. Vilensky L. Comparison of the life cycle of Trypanosoma acomys in Parapulex chefrensis with T. lewisi in Xenopsylla cheopis. MSc thesis. Jerusalem: Hebrew University; 1960

42. Welc-Falęciak R, Bajer A, Bednarska M, et al. Long term monitoring of Babesia microti infection in BALB/c mice, using nested PCR. Ann Agric Env Med. 2007;14:287-90.

43. Bednarska M, Bajer A, Drozdowska A, et al. Vertical transmission of Babesia microti in BALB/C mice: preliminary report. PLOS One in press.

44. Mierzejewska $E$, Welc-Falęciak R, Bednarska $M$, et al. The first evidence for vertical transmission of Babesia canis in a litter of Central Asian Shepherd dogs. Ann Agric Environ Med. 2014;21:500-3. doi:10.5604/12321966. 1120590.

45. Willi N, Meli L, et al. Haemotrope Mykoplasmen bei Hund und Katze: Übertragung, Diagnose, Prävalenz und Bedeutung in Europa. Schweiz Arch Für Tierheilkd. 2010;152:237-44. doi:10.1024/0036-7281/a000055.

\section{Submit your next manuscript to BioMed Central and we will help you at every step:}

- We accept pre-submission inquiries

- Our selector tool helps you to find the most relevant journal

- We provide round the clock customer support

- Convenient online submission

- Thorough peer review

- Inclusion in PubMed and all major indexing services

- Maximum visibility for your research

Submit your manuscript at www.biomedcentral.com/submit 